\title{
Polymer Nanocomposites for Photocatalytic Degradation and Photoinduced Utilizations of Azo-Dyes
}

\author{
Emily Z. Wang ${ }^{1}$, Yigui Wang ${ }^{2}$ and Dequan Xiao ${ }^{2, * \mathbb{D}}$ \\ 1 Department of Molecular Medicine, Cornell College of Veterinary Medicine Ithaca, Ithaca, NY 14853, USA; \\ zw63@cornell.edu \\ 2 Center for Integrative Materials Discovery, Department of Chemistry and Engineering, \\ University of New Haven, West Haven, CT 06515, USA; ywang@newhaven.edu \\ * Correspondence: dxiao@newhaven.edu
}

Citation: Wang, E.Z.; Wang, Y.; Xiao, D. Polymer Nanocomposites for Photocatalytic Degradation and Photoinduced Utilizations of Azo-Dyes. Polymers 2021, 13, 1215. https://doi.org/10.3390/ polym13081215

Academic Editor: Francesco Paolo La Mantia

Received: 1 March 2021

Accepted: 2 April 2021

Published: 9 April 2021

Publisher's Note: MDPI stays neutral with regard to jurisdictional claims in published maps and institutional affiliations.

Copyright: (c) 2021 by the authors. Licensee MDPI, Basel, Switzerland. This article is an open access article distributed under the terms and conditions of the Creative Commons Attribution (CC BY) license (https:// creativecommons.org/licenses/by/ $4.0 /)$

\begin{abstract}
Specially designed polymer nanocomposites can photo-catalytically degrade azo dyes in wastewater and textile effluents, among which $\mathrm{TiO}_{2}$-based nanocomposites are outstanding and extensively explored. Other nanocomposites based on natural polymers (i.e., chitosan and kaolin) and the oxides of $\mathrm{Al}, \mathrm{Au}, \mathrm{B}, \mathrm{Bi}, \mathrm{Fe}, \mathrm{Li}$, and $\mathrm{Zr}$ are commonly used. These nanocomposites have better photocatalytic efficiency than pure $\mathrm{TiO}_{2}$ through two considerations: (i) reducing the hole/electron recombination rate by stabilizing the excited electron in the conducting band, which can be achieved in $\mathrm{TiO}_{2}$-nanocomposites with graphene, graphene oxide, hexagonal boron nitride (h-BN), metal nanoparticles, or doping; (ii) decreasing the band energy of semiconductors by forming nanocomposites between $\mathrm{TiO}_{2}$ and other oxides or conducting polymers. Increasing the absorbance efficiency by forming special nanocomposites also increases photocatalytic performance. The photoinduced isomerization is exploited in biological systems, such as artificial muscles, and in technical fields such as memory storage and liquid crystal display. Heteroaryl azo dyes show remarkable shifts in photo-induced isomerization, which can be applied in biological and technical fields in place of azo dyes. The self-assembly methods can be employed to synthesize azo-dye polymer nanocomposites via three types of interactions: electrostatic interactions, London forces or dipole/dipole interactions between azo dyes, and photo alignments.
\end{abstract}

Keywords: photocatalytic degradation; azo-dyes; photo-induced isomerization; self-assembly; polymer nanocomposites

\section{Introduction}

Azo dyes are dye molecules containing azo $(-\mathrm{N}=\mathrm{N}-)$ groups. Color-related industries, such as fuel dyes, hair dyes, food dyes, and textile dyes, often use azo compounds [1,2]. Other important scientific fields use azo dyes as indicators for $\mathrm{pH}$ measurements, metal ion detection [3], and even $\mathrm{O}_{2}$ level monitoring. Azo dyes account for $60-70 \%$ of all dyes [4]. Some azo compounds have medical applications. For example, prontosil is an antibacterial drug that was discovered in 1932 after five years of testing thousands of compounds related to azo dyes for useful properties [5]. Figure 1 summarizes representative azo compounds that are commercially available along with their applications.

The outstanding properties of azo dyes invoke extensive applications. The applications of azo dyes in the textile industry naturally release a large number of azo dyes into the environment; thus, the potential hazardous impact of azo dyes on the environment is an imminent threat to the health of human beings [6]. Typical wastewater treatment methods include physical methods (e.g., coagulation-flocculation, adsorption, ultrasound, and membrane filtration), chemical methods (e.g., ozonation, sodium hypochlorite, Fenton reagent $\left(\mathrm{H}_{2} \mathrm{O}_{2}-\mathrm{Fe}(\mathrm{II})\right)$, and photochemical treatment), and biological treatments (e.g., decolorization by fungi, bacterial decolorization, and enzymatic decolorization) [7]. Recent reviews have been available in enzymatic decolorization of azo dyes in wastewater [8,9] and combined 
treatment approaches for large-scale wastewater treatments [10]. Advanced oxidation processes (AOPs) are highly broad-specificity chemical methods that can quickly convert azo dyes to eco-friendly final products such as $\mathrm{CO}_{2}$ and $\mathrm{H}_{2} \mathrm{O}$. Different combinations of AOPs and other methods top the list of publications, among which photochemical treatment is outstanding. Nanocomposites are photocatalysts in photochemical treatments. In this mini-review, firstly, we will review the development of polymer nanocomposites (most of them contained polymeric materials as a matrix) that are designed for photo-catalytic azo-dye removal in wastewater and textile effluents.<smiles>O=S(=O)([AlH2])c1cccc(N=Nc2ccc(Nc3ccccc3)cc2)c1</smiles>

Metanil yellow, $\mathrm{pH}$ indicator<smiles>Nc1ccc(/N=N/c2ccc(S(N)(=O)=O)cc2)c(N)c1</smiles>

Prontosil, antibacterial drug<smiles>Nc1ccc(/N=N/c2ccccc2)cc1</smiles>

Aniline yellow, vital staining<smiles>CN(C)c1ccc(/N=N/c2ccccc2C(=O)O)cc1</smiles>

Methyl red, pH indicator<smiles>CC(C)(C#N)N=NC(C)(C)C#N</smiles>

AIBN, radical initiator<smiles>CN(C)c1ccc(N=Nc2ccc(S(=O)(=O)O)cc2)cc1</smiles>

Methyl Orange, $\mathrm{pH}$ indicator

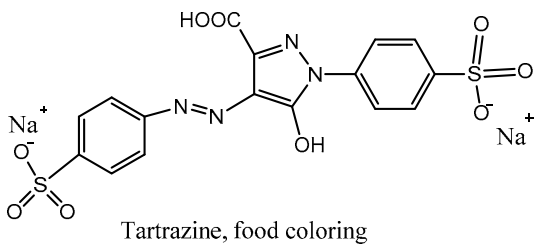<smiles>CCN(CC)c1ccc2nc3ccc(N=Nc4ccc(N(C)C)cc4)cc3[n+](-c3ccccc3)c2c1</smiles>

Janus green $\mathrm{B}$, vital staining, $\mathrm{O}_{2}$ indicator<smiles>CN(C)c1ccc(/N=N/c2ccccc2)cc1</smiles>

Acid red 33, hair dye<smiles>CCN(CC)c1ccc(/N=N/c2ccccc2)cc1</smiles>

Oil yellow DE, fuel dye

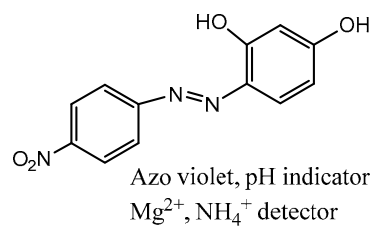

Disperse orange 3 , textile dye<smiles>Nc1cc(S(=O)(=O)[18OH])cc2cc(S(=O)(=O)[OH2+])c(N=Nc3ccccc3)c(O)c12</smiles><smiles>Nc1ccc(/N=N/c2ccc([N+](=O)[O-])cc2)cc1</smiles><smiles>Oc1ccc(/N=N/c2ccccc2)cc1</smiles>

4-hydroxyl Azobenzene, dye

Figure 1. Common azo dyes and their applications.

Besides the colors, azo-dye compounds display outstanding photo-induced properties. It is well known that cis- and trans-azo-dye compounds can be selectively converted into each other under the irradiation of different wavelengths of lights [11]. The cis-isomer is dominant under UV light while the trans-isomer is the major form in visible light [12]. The phosphorescence of azobenzene has not been reported, because the triplet state is not involved in photoisomerization of azobenzene [13]. However, when the photoisomerization is hindered or blocked, enhanced fluorescence can be observed. Figure 2 summarizes representative azo dyes that emit enhanced fluorescence. Fluorescence has been observed for rigid cyclic azo compounds 1-pyrazoline [14] and 2,3-diazabicyclo(2,2,2)oct-2-ene [15]. The compound 2,2'-bis(N-(2-pyridyl)methyl)diaminoazobenzene (AzoAMP-1) forms strong intramolecular hydrogen bonding that introduces a barrier to photoisomerization, so that 
AzoAMP-1 adopts a rigid planar structure to be more emissive than azobenzene at low temperatures [16]. Yoshino and co-workers introduced a bis(pentafluorophenyl) borane group to the 2-position of azobenzene ( $\mathrm{AB})$. The compounds $(\mathrm{R}=\mathrm{H}, \mathrm{OMe})$ produce the most intense green fluorescence (at $503 \mathrm{~nm}$ and $524 \mathrm{~nm}$ ) when they are irradiated separately by light at $386 \mathrm{~nm}$ and $439 \mathrm{~nm}$. Remarkably, the fluorescence emits at room temperature, and it is the most intense among all azo dyes that have been obtained so far [17]. In this mini-review, we summarize the progress in utilizing the photoinduced properties of azo dyes. We specifically focus on three azo-dye-based materials: photo-control machinery, nonlinear optical materials, and light-aligning crystals.

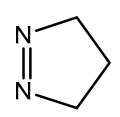

1-Pyrazoline

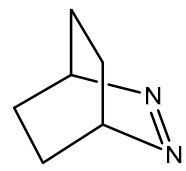<smiles></smiles>

AzoAMP1

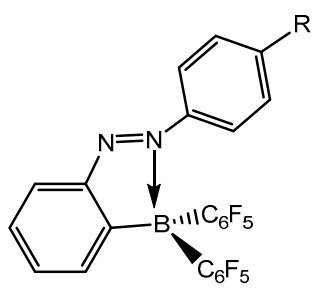

2-bis(pentafluorophenyl)borane Azobenzene

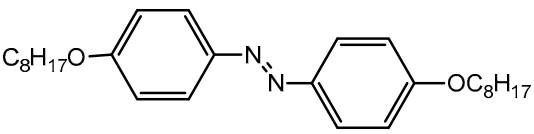

4,4'-dioctyloxyazobenzene (8AB8)

amphiphiles containing Azobenzene

Figure 2. Systems that emit enhanced fluorescence.

Polymer nanocomposites are versatile materials that can introduce multiple functions simultaneously, i.e., mechanical strength and catalytic or optical properties. Self-assembly is a facile, effective, and versatile technique that can introduce different azo dyes into polymer nanocomposites. A brief survey on the self-assembly method will be made in this mini-review.

At the end, we provide some promising outlooks for azo-dye-related research.

\section{Polymer Nanocomposites for Photocatalytic Degradation of Azo-Dyes}

\subsection{Nanocomposite Photocatalysts from Natural Polymers}

Chitosan is the most studied natural polymer to form nanocomposites. The $\mathrm{SnO}_{2} / \mathrm{ZnO}$ quantum dot (3-5 $\mathrm{nm}$ in diameter) heterojunction immobilized on crosslinked chitosan films $\left(\mathrm{SnO}_{2} / \mathrm{ZnO} /\right.$ chitosan films) were prepared successfully [18]. The nanocomposite showed good photocatalytic reactivity to remove methyl orange under visible light, and the catalyst was stable and efficient in the reaction conditions. However, chitosan-based nanocomposites are more often used as absorbents [19-23]. Kaolin is another commonly used natural material to form nanocomposites [24,25].

Chitosan and kaolin are exploited by their biodegradable, polycationic, and solid matrix properties in preparing nanocomposites. The photocatalytic properties come from semiconductor components and light irradiation. In other applications, $\mathrm{H}_{2} \mathrm{O}_{2}$, ultrasonic resources, and $\mathrm{pH}$ adjustment are required for preparing or applying nanocomposites (Table 1). 
Table 1. Nanocomposite photocatalysts based on natural materials.

\begin{tabular}{|c|c|c|c|c|c|c|c|}
\hline Base & Morphology & Advantages & Mechanisms & Usage & $\begin{array}{c}\text { Other } \\
\text { Requirements }\end{array}$ & $\begin{array}{c}\text { Stability + } \\
\text { Reusability }\end{array}$ & Reference \\
\hline Chitosan (CS) & $\begin{array}{l}\text { Quantum dot } \\
\mathrm{SnO}_{2} / \mathrm{ZnO} \\
(3-5 \mathrm{~nm}) \text { on } \\
\text { chitosan film }\end{array}$ & $\begin{array}{c}\text { Reduced } \\
\text { heterojunctions } \\
\text { are immobilized } \\
\text { on an absorbent } \\
\text { matrix; easy } \\
\text { separation }\end{array}$ & $\begin{array}{c}\cdot \mathrm{OH} \text { and } \cdot \mathrm{O}_{2}^{-} \\
\text {radicals are } \\
\text { active species }\end{array}$ & $\begin{array}{c}\text { Methyl orange } \\
\text { (MO) } \\
\text { degradation }\end{array}$ & Visible light & $\begin{array}{c}\text { Efficiency only } \\
\text { drops after } 3 \\
\text { runs }\end{array}$ & [18] \\
\hline Chitosan & $\begin{array}{c}\text { Chitosan- } \\
\text { layered } \mathrm{ZrP} \\
\text { nanoparticles } \\
\text { (NPs) }\end{array}$ & $\begin{array}{l}\text { Synergetic effect } \\
\text { (chitosan reduces } \\
\mathrm{Cr}(\mathrm{VI}) \text { then } \mathrm{ZrP} \\
\text { absorbs } \mathrm{Cr}(\mathrm{III}) \text { ) }\end{array}$ & $\begin{array}{l}\text { The superoxide } \\
\text { anions were } \\
\text { stabilized by } \mathrm{ZrP} \\
\text { or } \mathrm{CZrP}\end{array}$ & $\begin{array}{c}\mathrm{Cr}(\mathrm{VI}), \\
\text { Reactive blue } \\
21(\mathrm{RB}-21), \text { and } \\
\text { Reactive red } \\
141 \text { (R-141) }\end{array}$ & $\mathrm{H}_{2} \mathrm{O}_{2}$ & $\begin{array}{c}\text { Efficiency } \\
\text { unchanged } \\
\text { after } 3 \text { cycles }\end{array}$ & [19] \\
\hline Chitosan & $\begin{array}{l}\text { Chitosan- } \\
\text { coated CuO } \\
\text { NPs }\end{array}$ & Ecofriendly & $\begin{array}{c}\text { Bacteria inhibitor; } \\
\text { produces } \cdot \mathrm{OH} \\
\text { and superoxide } \\
\text { radicals }\end{array}$ & $\begin{array}{c}\text { Bacteria } \\
\text { inhibition; } \\
\text { Methyl blue } \\
\text { (MB) and } \\
\text { Congo red (CR) } \\
\text { removal }\end{array}$ & Sunlight & & [20] \\
\hline Chitosan & $\begin{array}{c}\text { Chitosan/carbon } \\
\text { nanoflowers } \\
(\mathrm{CNFs})\end{array}$ & $\begin{array}{c}\text { Chitosan is } \\
\text { biodegradable; } \\
\text { carbon } \\
\text { nanoflowers } \\
\text { act as an } \\
\text { absorbent }\end{array}$ & $\begin{array}{l}\text { CS/CNFs have a } \\
\text { positively } \\
\text { charged surface } \\
\text { and can form } \\
\text { hydrogen bonds }\end{array}$ & $\begin{array}{c}\text { Acid black } 1 \\
(\mathrm{AB}-1) \text { and } \\
\text { Congo red }(\mathrm{CR}) \\
\text { removal }\end{array}$ & & $\begin{array}{c}50-79 \% \\
\text { efficiency after } \\
4 \text { cycles } \\
\text { (remains) }\end{array}$ & [21] \\
\hline Chitosan & $\begin{array}{c}\text { Graphene } \\
\text { oxide platelets } \\
\text { are embedded } \\
\text { in a chitosan } \\
\text { matrix }\end{array}$ & $\begin{array}{l}\text { Cost effective; } \\
\text { sustainable }\end{array}$ & Absorbent & $\begin{array}{l}\text { Acid yellow } \\
(\mathrm{AY}) \text { and } \mathrm{Acid} \\
\text { blue }(\mathrm{AB}) \\
\text { removal }\end{array}$ & Ultrasound & $\begin{array}{c}87 \% \text { efficiency } \\
\text { after } 8 \text { cycles }\end{array}$ & {$[22]$} \\
\hline Scallop shell & $\begin{array}{c}\mathrm{Fe}_{3} \mathrm{O}_{4} \mathrm{NPs} \text { are } \\
\text { coated on a } \\
\text { shell surface }\end{array}$ & $\begin{array}{l}\text { Efficient; low } \\
\text { cost }\end{array}$ & Absorbent & $\begin{array}{c}\text { Reactive black } \\
5(\mathrm{RB}-5) \\
\text { removal }\end{array}$ & & $\begin{array}{c}100 \% \text { after } 6 \\
\text { consecutive } \\
\text { runs }\end{array}$ & [23] \\
\hline $\begin{array}{l}\text { Kaolinite/ } \\
\text { Chitosan }\end{array}$ & $\begin{array}{c}\text { Composite } \\
\text { beads with } \\
\text { different ratios; } \\
\text { self-assembly }\end{array}$ & $\begin{array}{l}\text { Easy fabrication; } \\
\text { eco-friendly }\end{array}$ & $\begin{array}{l}\text { Chitosan has } \\
\text { polycationic } \\
\text { nature }\end{array}$ & $\begin{array}{l}\text { Remazol red } \\
(\mathrm{RR})\end{array}$ & $\mathrm{pH}$ & & [24] \\
\hline Kaolin & $\begin{array}{l}\text { Kaolin is } \\
\text { coated with } \\
\mathrm{Fe}_{3} \mathrm{O}_{4} \text { NPS }\end{array}$ & $\begin{array}{c}\text { Easy separation } \\
\text { by magnets }\end{array}$ & Adsorbent & $\begin{array}{l}\text { Acid red } 14 \\
\quad(\text { AR-14) }\end{array}$ & & $\begin{array}{c}\text { Efficiency } \\
88.43 \% \text { after } 6 \\
\text { cycles }\end{array}$ & [25] \\
\hline
\end{tabular}

\section{2. $\mathrm{TiO}_{2}$ Based Nanocomposites}

Many photocatalysts include $\mathrm{TiO}_{2}$ (Table 2). Stengl et al. synthesized hexagonal boron nitride (h-BN)- $\mathrm{TiO}_{2}$ nanocomposites by thermal hydrolysis of titanium peroxo-complexes in the presence of exfoliated h-BN. The highest rate constants for photocatalytic removal of orange II and reactive black 5 were $k=0.0762 \mathrm{~min}^{-1}$ and $0.0164 \mathrm{~min}^{-1}$ under UV and visible light irradiation, respectively [26]. Sharma et al. obtained surfactant-aided $\mathrm{TiO}_{2-}$ $\mathrm{MgO}$ nanocomposite (Ti-M-S) by sol-gel process with the aid of sodium dodecyl sulfate as structure-directing anionic surfactant. The Ti-M-S efficiently removed methyl orange and methylene blue under visible light irradiation [27]. Karimzadeh and Bahrami [28] used L-cysteine and cadmium sulfide (CdS) as promoted agents to develop new $\mathrm{TiO}_{2-}$ based nanocomposites and successfully improved the photo-catalytic activity of $\mathrm{TiO}_{2}$. Fly ash supported photocatalytic nanocomposite poly(3,4-ethylenedioxythiophene) $/ \mathrm{TiO}_{2}$ has extended efficiency to remove reactive red 45 under solar light [29]. 
Table 2. $\mathrm{TiO}_{2}$-based nanocomposites for photo-degradation of azo dyes.

\begin{tabular}{|c|c|c|c|c|c|c|}
\hline Morphology & $\begin{array}{c}\text { Improvements } \\
\text { Over } \mathrm{TiO}_{2}\end{array}$ & Mechanisms & Usage & Light & $\begin{array}{l}\text { Stability + } \\
\text { Reusability }\end{array}$ & References \\
\hline h-BN-TiO 2 & $\begin{array}{l}\text { Band gap energy } \\
\mathrm{E}_{\mathrm{g}}=\sim 2.3-3.3 \mathrm{eV}\end{array}$ & $\begin{array}{c}\text { h-BN (like graphene) } \\
\text { accepts electrons and } \\
\text { inhibits hole/electron } \\
\left(\mathrm{h}^{+} / \mathrm{e}^{-}\right) \\
\text {recombination }\end{array}$ & $\begin{array}{l}\text { Orange II (OII); } \\
\text { Reactive black } 5 \\
\text { (RB-5) }\end{array}$ & $\begin{array}{c}\text { UV } \\
\text { Visible }\end{array}$ & $\begin{array}{c}\mathrm{k}=0.0762 \mathrm{~min}^{-1} \\
\quad(\mathrm{OII}) ; \\
\mathrm{k}=0.0164 \min ^{-1} \\
(\mathrm{RB}-5)\end{array}$ & [26] \\
\hline $\begin{array}{c}\mathrm{MgO} \\
\text { nanoparticles } \\
\text { within a } \mathrm{TiO}_{2} \\
\text { framework via } \\
\text { surfactant-aided } \\
\text { sol-gel } \\
\text { approaches } \\
\end{array}$ & $\begin{array}{l}\text { Surfactant ensures } \\
\text { uniform dispersion } \\
\text { of the magnesium } \\
\text { dopant onto } \\
\text { titanium }\end{array}$ & $\begin{array}{l}\text { High } \mathrm{MgO} \text { content } \\
\text { provides a high } \\
\text { energy level for } \\
\text { photo-degradation }\end{array}$ & $\begin{array}{l}\text { Methyl orange } \\
\text { (MO); } \\
\text { Methylene blue } \\
\text { (MB) }\end{array}$ & Visible & $\begin{array}{l}82.4 \%(\mathrm{MB}) \\
77.8 \%(\mathrm{MO})\end{array}$ & [27] \\
\hline $\begin{array}{l}\mathrm{TiO}_{2} \text { was } \\
\text { immobilized on } \\
\text { the surface of fly } \\
\text { ash, on which } \\
\text { conductive } \\
\text { polymer was } \\
\text { grafted }\end{array}$ & $\begin{array}{l}\text { Reduced band gap } \\
\left(\mathrm{E}_{\mathrm{g}}=1.5-3.0 \mathrm{eV} \text { for }\right. \\
\text { conductive } \\
\text { polymer) easy } \\
\text { removal and reuse }\end{array}$ & $\begin{array}{l}\text { Semiconductor } \\
\text { produces } \cdot \mathrm{OH} \text { and } \\
\cdot \mathrm{O}_{2}^{-} \text {radicals }\end{array}$ & $\begin{array}{l}\text { Reactive red } 45 \\
\quad(\text { RR-45) }\end{array}$ & Visible + Solar & $\begin{array}{c}\text { Catalytic } \\
\text { efficiency } \\
\text { dropped quickly } \\
\text { after the first run }\end{array}$ & [29] \\
\hline $\begin{array}{l}\mathrm{N} \text {-(urea) and } \mathrm{C}-\mathrm{N} \\
\text { (L-asparagine)- } \\
\text { doped } \mathrm{TiO}_{2}-\mathrm{CuO} \\
\text { nanocomposite }\end{array}$ & $\begin{array}{l}\mathrm{TiO}_{2} \text { band gap was } \\
\text { narrowed to the } \\
\text { visible light region }\end{array}$ & $\begin{array}{c}\mathrm{CuO} \text { is a p-type } \\
\text { semiconductor } \\
\left(\mathrm{E}_{\mathrm{g}}=1.2-1.5 \mathrm{eV}\right), \\
\text { and } \mathrm{N} \text {-cap reduces } \\
\mathrm{h}^{+} / \mathrm{e}^{-} \text {recombination }\end{array}$ & $\begin{array}{l}\text { Direct red } 16 \\
\quad(\mathrm{DR}-16)\end{array}$ & Visible & $\mathrm{k}=0.0403 \mathrm{~min}^{-1}$ & [30] \\
\hline $\begin{array}{l}\text { N-Fe co-doped- } \\
\mathrm{TiO}_{2} / \mathrm{SiO}_{2}\end{array}$ & $\begin{array}{l}\text { Simultaneously } \\
\text { remove } \mathrm{Cr}(\mathrm{VI}) \text { and } \\
\text { azo dyes } \\
\text { (using continuous } \\
\text { flow photo reactor) }\end{array}$ & $\begin{array}{l}\text { The non-metal anion } \\
\text { dopants increase the } \\
\text { percentage of the } \\
\text { anatase phase of } \mathrm{TiO}_{2} ; \\
\mathrm{SiO}_{2} \text { increases surface } \\
\text { area }\end{array}$ & $\begin{array}{c}\text { Cr(VI) } \\
\text { Basic red } 29 \\
\text { (BR-29); } \\
\text { Basic blue } 41 \\
\text { (BB-41); } \\
\text { Basic yellow } 51 \\
\text { (BY-51) }\end{array}$ & Visible or solar & $\begin{array}{c}91.73 \%\left(\mathrm{Cr}^{6+}\right) \\
85.64 \%(\mathrm{BR}-29) \\
87.23 \%(\mathrm{BB}-41) \\
58.59 \%(\mathrm{BY}-51) ; \\
70 \% \text { efficiency } \\
\text { after the } 7 \text { th } 12 \mathrm{~h} \\
\text { cycle }\end{array}$ & [31] \\
\hline $\begin{array}{c}\text { Cu-doped } \\
\mathrm{TiO}_{2}-\mathrm{Bi}_{2} \mathrm{O}_{3}\end{array}$ & $\begin{array}{l}\text { Better efficiency } \\
\text { using visible light }\end{array}$ & $\begin{array}{c}\mathrm{TiO}_{2} / \mathrm{Bi}_{2} \mathrm{O}_{3} \text { prevents } \\
\text { recombination rates } \\
\text { of photo-induced } \\
\mathrm{h}^{+} / \mathrm{e}^{-} \text {pairs; } \\
\mathrm{Cu} \text { reduce band gap } \\
\text { to visible region }\end{array}$ & $\begin{array}{l}\text { Methyl orange } \\
\text { (MO) }\end{array}$ & $\begin{array}{l}\text { LED lamp } \\
(\lambda>410 \mathrm{~nm})\end{array}$ & $\begin{array}{l}79 \% \text { efficiency } \\
\text { after } 5 \text { cycles }\end{array}$ & [32] \\
\hline $\begin{array}{c}\mathrm{Mn}, \mathrm{Mo} \text {, and } \\
\mathrm{La} / \mathrm{TiO}_{2} \\
\text { activated carbon } \\
\text { (AC) }\end{array}$ & $\begin{array}{l}\text { High absorption } \\
\text { ability in the visible } \\
\text { light region; } \\
\text { cost effective; } \\
\text { easy removal }\end{array}$ & $\begin{array}{l}\text { Metals reduce the } \\
\text { recombination rates } \\
\text { of hole/electron } \\
\left(\mathrm{h}^{+} / \mathrm{e}^{-}\right) \text {pairs }\end{array}$ & $\begin{array}{c}\text { Reactive red } 198 \\
\quad(\text { RR-198); } \\
\text { textile wastewater }\end{array}$ & Visible & $\begin{array}{c}91 \% \text { (RB-198) } \\
52.78 \% \text { efficiency } \\
\text { after the 4th run }\end{array}$ & [33] \\
\hline $\begin{array}{c}\mathrm{Fe}^{3+} \text {-doped } \\
\mathrm{TiO}_{2} \text {-bentonite } \\
\text { clay }\end{array}$ & $\begin{array}{l}\text { Remove total } \\
\text { organic carbon } \\
\text { (TOC) }\end{array}$ & $\begin{array}{c}\text { Photo-Fenton } \\
\text { reaction; } \\
\text { nanocomposite } \\
\text { reduces hole/electron } \\
\left(\mathrm{h}^{+} / \mathrm{e}^{-}\right) \\
\text {recombination rate }\end{array}$ & Orange II (OII) & 254 nm UVC & $100 \%$ decoloring & [34] \\
\hline $\begin{array}{c}\mathrm{ZnO} / \mathrm{TiO}_{2} \\
\text { Phase } \\
\text { transformations }\end{array}$ & $\begin{array}{c}\mathrm{ZnO} \text { absorbs a } \\
\text { larger fraction of } \\
\mathrm{UV} \text { light than } \mathrm{TiO}_{2}\end{array}$ & $\begin{array}{l}\text { Large surface area; } \\
\text { hole can transfer from } \\
\mathrm{TiO}_{2} \text { valence band to } \\
\mathrm{ZnO} \text { valence band }\end{array}$ & Congo red (CR) & UVC lamp & $\begin{array}{l}\text { discoloring after } \\
10 \mathrm{~min}\end{array}$ & [35] \\
\hline $\begin{array}{c}\text { Ferrites } \\
\text { encapsulated } \\
\text { with } \mathrm{TiO}_{2}\end{array}$ & $\begin{array}{l}\text { Easy catalyst } \\
\text { recovery }\end{array}$ & $\begin{array}{c}\text { Larger specific area } \\
\left(43.2 \mathrm{~m}^{2} / \mathrm{g}\right) \text { than } \mathrm{TiO}_{2} \\
\left(31.1 \mathrm{~m}^{2} / \mathrm{g}\right) \\
\text { Dyes degrades in bulk } \\
\text { solution by radicals }\end{array}$ & Textile effluents & $\begin{array}{c}\text { UV } \\
(253.7 \mathrm{~nm})\end{array}$ & $\begin{array}{c}65 \% \text { efficiency at } \\
\text { pH = 7; } \\
80 \% \text { efficiency at } \\
\text { pH }=12\end{array}$ & [36] \\
\hline $\mathrm{Fe}_{3} \mathrm{O}_{4} / \mathrm{SiO}_{2} / \mathrm{TiO}_{2}$ & $\begin{array}{c}\mathrm{Fe}_{3} \mathrm{O}_{4} \text {-core was } \\
\text { coated with silica } \\
\left(\mathrm{SiO}_{2}\right) \text {, which was, } \\
\text { in turn, coated with } \\
\mathrm{TiO}_{2}\end{array}$ & $\begin{array}{l}\text { Core } \mathrm{Fe}_{3} \mathrm{O}_{4} \mathrm{NPs} \\
\mathrm{SiO}_{2} \text {-inner layer } \\
\mathrm{TiO}_{2} \text { - outer layer }\end{array}$ & $\begin{array}{l}\text { Methyl Orange } \\
\text { (MO); } \\
\text { Methylene blue } \\
\text { (MB) }\end{array}$ & UV (365 nm) & $\begin{array}{c}90.2 \%(\mathrm{MO}) \\
100 \%(\mathrm{MB}) ; \\
\text { no efficiency } \\
\text { decrease after } 5 \\
\text { runs }\end{array}$ & [37] \\
\hline
\end{tabular}


Table 2. Cont.

\begin{tabular}{|c|c|c|c|c|c|c|}
\hline Morphology & $\begin{array}{c}\text { Improvements } \\
\text { Over } \mathrm{TiO}_{2}\end{array}$ & Mechanisms & Usage & Light & $\begin{array}{c}\text { Stability + } \\
\text { Reusability }\end{array}$ & References \\
\hline $\mathrm{TiO}_{2}$-hydrogel & $\begin{array}{l}\text { Good removal } \\
\text { performance; } \\
\text { pH sensitivity } \\
\text { facilitates retrieval } \\
\text { of catalyst at the } \\
\text { end }\end{array}$ & $\begin{array}{c}\mathrm{TiO}_{2} \text { entrapped in the } \\
\text { hydrogel }\end{array}$ & $\begin{array}{l}\text { Acid orange } 7 \\
\text { (AO-7); } \\
\text { Acid red } 88 \\
\text { (AR-88) }\end{array}$ & UV & $\begin{array}{l}98 \% \text { AR- } 88 \\
71 \% \text { AO-7 }\end{array}$ & [38] \\
\hline $\begin{array}{c}\mathrm{TiO}_{2} \\
\text { NPs/hydrogel }\end{array}$ & $\begin{array}{c}\text { Hydrogel as } \\
\text { supporting material } \\
\text { for } \mathrm{TiO}_{2} ; \\
\text { easy removal }\end{array}$ & $\begin{array}{c}\text { Hydrogel both } \\
\text { supports } \mathrm{TiO}_{2} \text { and } \\
\text { absorbs pollutants }\end{array}$ & $\begin{array}{c}\text { Acid red } 18 \\
\text { (AR-18); } \\
\text { Acid blue } 113 \\
\text { (AB-113); } \\
\text { Reactive black } 5 \\
\text { (RB-5) } \\
\text { Direct black-78 }\end{array}$ & $\begin{array}{l}\text { UV-sun-like } \\
\text { illumination }\end{array}$ & $\begin{array}{l}85 \% \text { efficiency } \\
\text { after 3rd cycle }\end{array}$ & [39] \\
\hline $\begin{array}{c}\mathrm{TiO}_{2}-\mathrm{SiO}_{2} \text { hollow } \\
\text { nanospheres }\end{array}$ & $\begin{array}{l}\text { Enhanced } \\
\text { photocatalytic } \\
\text { performance }\end{array}$ & $\begin{array}{l}\text { Larger surface area } \\
\text { (up to } 1105 \mathrm{~m}^{2} / \mathrm{g} \text { ) }\end{array}$ & $\begin{array}{l}\text { Methyl orange } \\
\text { (MO); } \\
\text { Phenol }\end{array}$ & $\begin{array}{l}\text { UV light; } \\
\text { sunlight }\end{array}$ & $95 \% \mathrm{MO}$ & [40] \\
\hline $\mathrm{TiO}_{2}-\mathrm{SiO}_{2}$ & $\begin{array}{l}\text { Sol-gel methods; } \\
\text { enhanced } \\
\text { photocatalytic and } \\
\text { thermal properties }\end{array}$ & $\begin{array}{l}\text { Ti-O-Si bond and } \\
\text { amorphous } \mathrm{SiO}_{2} \\
\text { increases the } \mathrm{stability} \\
\text { of anatase } \mathrm{TiO}_{2} \\
\text { increases surface area, } \\
\text { and limits the growth } \\
\text { of crystallites }\end{array}$ & Congo red (CR) & UVC lamp & $98 \% \mathrm{CR}$ & [41] \\
\hline $\begin{array}{c}\mathrm{Au} \\
\mathrm{NPs} / \text { Preyssler } \\
\text { acid } / \mathrm{TiO}_{2}\end{array}$ & $\begin{array}{c}\text { Eco-friendly; } \\
\text { no free } \mathrm{Au} \\
\text { contamination }\end{array}$ & $\begin{array}{c}\text { Au-NPs increase } \\
\text { charge separation } \\
\text { between the excited } \\
\text { electron }\left(\mathrm{e}^{-}\right) \text {and hole } \\
\left(\mathrm{h}^{+}\right) ; \\
\text {Preyssler is both a } \\
\text { stabilizer and a } \\
\text { reducing agent }\end{array}$ & Malachite green & UV & $\begin{array}{c}95 \% \text { efficiency } \\
\text { after the 3rd cycle }\end{array}$ & [42] \\
\hline $\begin{array}{c}\text { Sonic- } \\
\mathrm{TiO}_{2} / \mathrm{Bi}_{2} \mathrm{O}_{3}\end{array}$ & $\begin{array}{l}\text { More efficient than } \\
\text { pure } \mathrm{TiO}_{2} \text { and } \\
\text { stirred } \mathrm{TiO}_{2} / \mathrm{Bi}_{2} \mathrm{O}_{3}\end{array}$ & $\begin{array}{l}\text { High energy of } \\
\text { ultrasonic wave } \\
\text { promotes the } \\
\text { crystallization of the } \\
\mathrm{TiO}_{2} \mathrm{NPs} \text { and } \mathrm{Bi}_{2} \mathrm{O}_{3} \\
\mathrm{NPs} \text { that grow on the } \\
\text { surface to benefit the } \\
\text { charge transfer }\end{array}$ & Orange II (OII) & $\begin{array}{c}\text { Visible } \\
(\lambda>400 \mathrm{~nm})\end{array}$ & $94.7 \%$ OII & [43] \\
\hline $\begin{array}{l}\text { Graphene } / \mathrm{TiO}_{2-} \\
\mathrm{Ag}\end{array}$ & $\begin{array}{l}\text { Extended light } \\
\text { absorption range }\end{array}$ & $\begin{array}{l}\text { Band gaps of } \\
\text { nanocomposites are } \\
\sim 3.05-3.09 \mathrm{eV}\end{array}$ & Amaranth dye & $\begin{array}{l}\text { UV; } \\
\text { Sun }\end{array}$ & $\begin{array}{c}85.3-98 \% \\
\text { graphene } / \mathrm{TiO}_{2-} \\
\mathrm{Ag} ; \\
\text { 99\% reduced } \\
\text { graphene } / \mathrm{TiO}_{2-} \\
\mathrm{Ag}\end{array}$ & [44] \\
\hline $\begin{array}{c}\mathrm{ZnO} / \mathrm{TiO}_{2} \text { coated } \\
\text { on stainless-steel } \\
\text { electrode }\end{array}$ & $\begin{array}{l}\text { Combined photo- } \\
\text { electrocatalytic and } \\
\text { electrochemical } \\
\text { methods }\end{array}$ & $\begin{array}{l}\mathrm{ZnO} / \mathrm{TiO}_{2} \text { composite } \\
\text { reduced the band gap; } \\
\text { electrical field } \\
\text { separate } \\
\text { photo-induced } \\
\text { electron-hole pairs }\end{array}$ & $\begin{array}{l}\text { Acid orange } 7 \\
\text { (AO-7); } \\
\text { Chemical (C1); } \\
\text { chemicaloxygen } \\
\text { demand (COD) }\end{array}$ & Solar irradiation & $\begin{array}{l}97 \% \text { AO-7 } \\
99 \% \text { COD }\end{array}$ & [45] \\
\hline
\end{tabular}

Doping $\mathrm{TiO}_{2}$ has become a popular way to improve the photocatalytic activity of $\mathrm{TiO}_{2}$. Zangeneh et al. [30] doped $\mathrm{TiO}_{2}-\mathrm{CuO}$ with $\mathrm{N}(\mathrm{Urea})$ and $\mathrm{C}-\mathrm{N}$ (L-Asparagine) and found that $\mathrm{C}-\mathrm{N}$ doped $\mathrm{TiO}_{2}-\mathrm{CuO}$ had the highest photocatalytic activity for direct red 16 removal. A novel fixed-bed continuous-flow photoreactor was developed using N-Fedoped $\mathrm{TiO}_{2} / \mathrm{SiO}_{2}$ and visible light to simultaneously remove $\mathrm{Cr}(\mathrm{VI})$ and azo dyes [31]. The $\mathrm{Cu}$ doped $\mathrm{TiO}_{2}-\mathrm{Bi}_{2} \mathrm{O}_{3}$ hybrid had the best photocatalytic activity with $1 \% \mathrm{Cu}$ and $8 \%$ $\mathrm{Bi}_{2} \mathrm{O}_{3}$ in visible light [32]. The $\mathrm{Mn}, \mathrm{Mo}$, and $\mathrm{La} / \mathrm{TiO}_{2} /$ activated carbon (AC) exhibited 
high absorption ability in the visible light region [33], while the $\mathrm{Fe}^{3+}$ doped $\mathrm{TiO}_{2}$ efficiently removed nonbiodegradable orange II [34].

Nanocomposites of $\mathrm{TiO}_{2}$ could be formed in other ways. Heat treatment of $\mathrm{ZnO} / \mathrm{TiO}_{2}$ transformed the nanocomposite into $\mathrm{ZnTiO}_{3}$ and $\mathrm{Zn}_{2} \mathrm{TiO}_{4}$ [35]. The $\mathrm{TiO}_{2}$ component has been included in core-shell nanospheres of which the cores were magnetic. For instance, the $\mathrm{TiO}_{2}$ that encapsulated ferrites could enhance the removal of azo-dye in textile effluents under both low- and high-energy lamps [36]. The $\mathrm{Fe}_{3} \mathrm{O}_{4} / \mathrm{SiO}_{2} / \mathrm{TiO}_{2}$ nanospheres removed $90.2 \%$ and $100 \%$ of binary methyl orange and methylene blue in aqueous solution under UV light irradiation ( $365 \mathrm{~nm}$ ) for $5 \mathrm{~h}$ [37]. In addition, $\mathrm{TiO}_{2}$ based nanocomposites can be formed as hydrogel. The $\mathrm{TiO}_{2}$ component did not affect the already formed covalent bonds within the polymer network in the $\mathrm{TiO}_{2} /$ hydrogel nanocomposites, but the colloidal $\mathrm{TiO}_{2}$ could completely remove color index (C.I.) acid red 18, C.I. acid blue 113, C.I. reactive black 5, and C.I. direct blue 78 [38]. The $\mathrm{pH}$-sensitive $\mathrm{TiO}_{2}$-containing hydrogel could remove $94 \%$ acid red 88 and $71 \%$ acid orange 7 in 30 min under UV light, and the catalysts could be retrieved at the end of the reaction [39]. Furthermore, the uniform $\mathrm{TiO}_{2}-\mathrm{SiO}_{2}$ nanospheres had remarkably enhanced photocatalytic performance [40,41], while the Au nanoparticles (NPs) decorated $\mathrm{TiO}_{2}$-formed nanocomposites with Preyssler acid that could efficiently remove malachite green under $\mathrm{UV}$ light irradiation [42]. The $\mathrm{TiO}_{2} / \mathrm{Bi}_{2} \mathrm{O}_{3}$ nanocomposites (from the ultrasonic-assisted synthesis) increased the removal efficiency of orange II to 94.7\% (from $44 \%$ for pure $\mathrm{TiO}_{2}$ nanoparticles) [43]. At last, the ternary graphene $/ \mathrm{TiO}_{2}-\mathrm{Ag}$ composites remarkably removed $85.3-98 \%$ of amaranth dye in $2 \mathrm{~h}$ under UV and solar irradiation [44], and the $\mathrm{ZnO} / \mathrm{TiO}_{2}$ nanocomposites coated on stainless-steel electrodes are powerful photoelectrocatalysts, because they enhance hydroxyl radical production [45]. $\mathrm{Yu}$ and coworkers [46] prepared a tubular titania nanostructure via layer-by-layer selfassembly, and the photocatalytic efficiency of the nanostructure toward the degradation of methyl orange was found to be dependent on the coating thickness.

\subsection{Photocatalytic Mechanism of $\mathrm{TiO}_{2}$ Nanocomposites}

A typical reaction mechanism is given in Figure 3 for graphene/ $\mathrm{TiO}_{2}-\mathrm{Ag}$ nanocomposites to photocatalytic degradation of azo dyes.

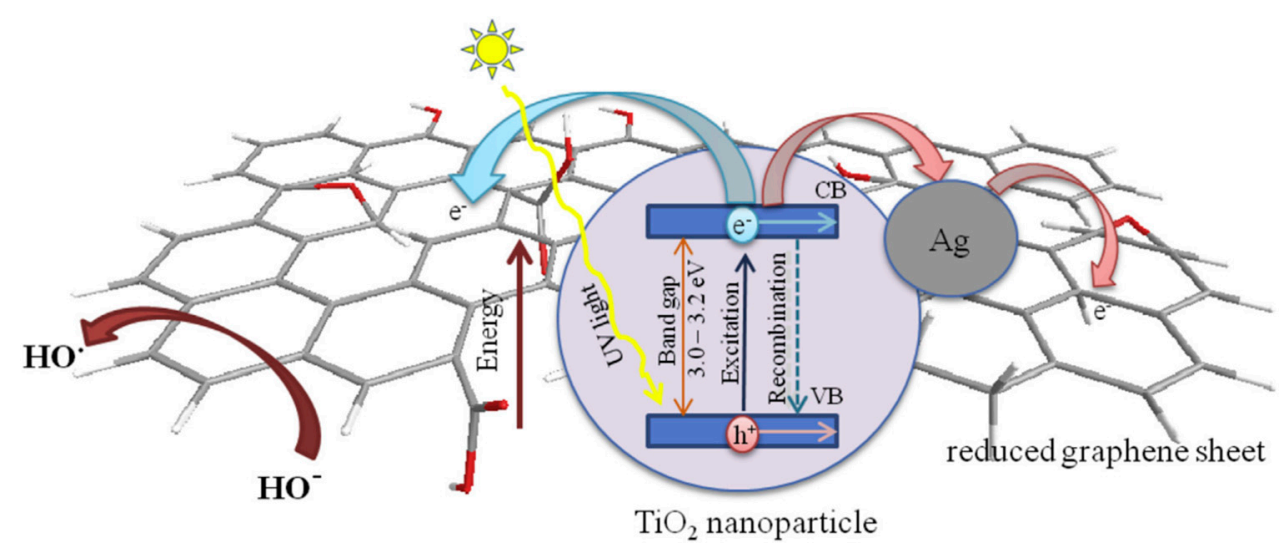

Figure 3. The photocatalytic mechanism of graphene $/ \mathrm{TiO}_{2}-\mathrm{Ag}$ nanocomposites [44]. Reproduced with the permission of Mater. Chem. Phys.

Absorption of light excites the electrons from the valence band that are transferred to the conducting band of the semiconductor causing hole/electron $\left(\mathrm{h}^{+} / \mathrm{e}^{-}\right)$separation. This results in the reaction of electrons in the conducting band with oxygen to form $\cdot \mathrm{O}_{2}{ }^{-}$ superoxide radicals and holes in the valence band with the water to form $\cdot \mathrm{OH}$ radicals responsible for the oxidation process of azo dyes.

$$
\begin{aligned}
& \mathrm{O}_{2}+\mathrm{e}^{-} \rightarrow \cdot \mathrm{O}_{2}^{-} \\
& \mathrm{H}_{2} \mathrm{O}+\mathrm{h}^{+} \rightarrow \cdot \mathrm{OH}
\end{aligned}
$$


The $\mathrm{TiO}_{2}$ semiconductors have a large band gap $\left(\mathrm{E}_{\mathrm{g}}=3.2 \mathrm{eV}\right)$ so that only UV light can excite electrons from the valence band (VB) to the conducting band (CB). In addition, $\mathrm{TiO}_{2}$ semiconductors have high hole/electron $\left(\mathrm{h}^{+} / \mathrm{e}^{-}\right)$recombination rates. Therefore, there are two ways to enhance photocatalytic efficiency, i.e., reducing the energy gap and lowering the $\mathrm{h}^{+} / \mathrm{e}^{-}$recombination rate. Table 2 summarizes the specific ways to achieve this goal. In the example, the electrons in the conducting band can move to a graphene surface via $\mathrm{Ag}$ or a graphene oxide surface; therefore, the hole/electron recommendation on $\mathrm{TiO}_{2}$ is eliminated. The hexagonal boron nitride behaviors, such as graphene and doping, is an efficient way to reduce hole/electron recommendation rates. The benefit of reducing the band gap of semiconductors is to utilize the abundant visible lights of solar energy. The band gap reductions are usually achieved through forming nanocomposites between $\mathrm{TiO}_{2}$ and other metal oxides or conducting polymers.

\subsection{Other Nanocomposite Photocatalysts}

Other photocatalysts (Table 3) for the degradation of azo dyes were reported in the form of nanocomposites based on Al [47], $\mathrm{Au}$ [48], $\mathrm{Bi}$ [49-51], Fe [52-55], Li [56], Ni [57], and $\mathrm{Zr}$ [58]. The Fe-based photocatalysts are exploited for their easy separation due to the fact of their magnetic properties.

Table 3. Other nanocomposites for photo-degradation of azo dyes.

\begin{tabular}{|c|c|c|c|c|c|c|}
\hline Morphology & Advantages & Mechanisms & Usage & Light & $\begin{array}{c}\text { Stability + } \\
\text { Reusability }\end{array}$ & References \\
\hline Rice-like $\mathrm{Ag} / \mathrm{Al}_{2} \mathrm{O}_{3}$ & $\begin{array}{l}\text { Good surface:volume } \\
\text { ratio; } \\
\text { good absorption; } \\
\text { Capacity for } \mathrm{Pb}^{2+}(250 \\
\mathrm{mg} / \mathrm{g})\end{array}$ & $\begin{array}{l}\text { Surface area } \\
241.219 \mathrm{~m}^{2} / \mathrm{g}\end{array}$ & $\begin{array}{l}\mathrm{Pd}^{2+} ; \\
\text { Acid violet } 7 \\
\quad(\mathrm{AV}-7)\end{array}$ & Visible & $\begin{array}{c}86.7-100 \% \text { AV-7; } \\
\text { absorbs } \mathrm{Pb}^{2+} \\
(215 \mathrm{mg} / \mathrm{g})\end{array}$ & [47] \\
\hline$\frac{\mathrm{Au}}{\mathrm{NPs} /\left(\mathrm{H}_{6} \mathrm{P}_{2} \mathrm{~W}_{18} \mathrm{O}_{62}\right)}$ & $\begin{array}{l}\text { Au nanoparticles } \\
\text { were incorporated in } \\
\text { Wells-Dawson } \\
\text { hetero-polyacid } \\
\text { nanocomposite film }\end{array}$ & $\begin{array}{l}\text { Heteropolyacids are } \\
\text { powerful oxidants; } \\
\text { reduced form is a } \\
\text { strong reducing } \\
\text { reagent and } \\
\text { stabilizer }\end{array}$ & $\begin{array}{l}\text { Methyl orange } \\
(\mathrm{MeO}) ; \\
\text { Methylene read } \\
(\mathrm{MR})\end{array}$ & UV $254 \mathrm{~nm}$ & $\begin{array}{l}96 \% \mathrm{MeO} \\
87.2 \% \mathrm{MR}\end{array}$ & {$[48]$} \\
\hline $\mathrm{CuBi}_{2} \mathrm{O}_{4} / \mathrm{Bi}_{3} \mathrm{ClO}_{4}$ & $\begin{array}{l}\text { Strong visible light } \\
\text { absorption; } \\
\text { fine particle size; } \\
\text { proper band gap; } \\
\text { high charge } \\
\text { separation } \\
\text { efficiency }\end{array}$ & $\begin{array}{c}\text { Hole }\left(\mathrm{h}^{+}\right) \text {and } \\
\text { superoxide radical } \\
\left(\cdot \mathrm{O}_{2}^{-}\right) \text {are } \\
\text { prevailing active } \\
\text { species }\end{array}$ & $\begin{array}{l}\text { Acid brown } 14 \\
\text { (AC-14) }\end{array}$ & Visible & $\begin{array}{c}92 \% \text { efficiency } \\
(\mathrm{AC}-14) ; \\
75 \% \text { TOC } \\
\text { removal }\end{array}$ & {$[49]$} \\
\hline $\begin{array}{l}\mathrm{Bi}_{2} \mathrm{O}_{3} / \mathrm{Nexar} \\
\text { polymer }\end{array}$ & $\begin{array}{c}\text { Efficient; } \\
\text { environmentally } \\
\text { friendly; } \\
\text { easy regeneration and } \\
\text { reuse }\end{array}$ & $\begin{array}{c}\mathrm{Bi}_{2} \mathrm{O}_{3} \\
\mathrm{E}_{\mathrm{g}}=2.1-2.8 \mathrm{eV} \\
\text { Nexar-membrane }\end{array}$ & $\begin{array}{l}\text { Methyl orange } \\
\text { (MO); } \\
\text { Methylene blue } \\
\text { (MB) }\end{array}$ & UV-vis or Blue & $\begin{array}{l}53 \% \text { dyes } \\
\text { membranes are } \\
\text { processed and } \\
\text { restored }\end{array}$ & {$[50]$} \\
\hline $\mathrm{NiO} / \mathrm{Bi}_{2} \mathrm{O}_{3} / \mathrm{Bi}_{3} \mathrm{ClO}_{4}$ & $\begin{array}{l}\text { Effective separation } \\
\text { and transfer of the } \\
\text { photoexcited } \\
\text { electron-hole pairs }\end{array}$ & $\begin{array}{c}\text { Photoexcited } \\
\text { superoxide radicals } \\
\text { and holes are } \\
\text { prevailing active } \\
\text { sites }\end{array}$ & $\begin{array}{l}\text { Acid red } 88 \\
\quad(\text { AR-88) }\end{array}$ & Visible & $\begin{array}{l}\text { 89\% AR-88; } \\
95 \% \text { efficiency } \\
\text { after } 4 \text { cycles }\end{array}$ & {$[51]$} \\
\hline $\begin{array}{c}\mathrm{Fe}_{3} \mathrm{O}_{4}-\mathrm{Pd} / \\
\text { pepper-extract }\end{array}$ & $\begin{array}{l}\text { Magnetic separation; } \\
\text { hydrothermal } \\
\text { procedure } \\
\text { (nanostructures have } \\
\text { preferential and } \\
\text { controlled shape and } \\
\text { size) }\end{array}$ & $\begin{array}{l}\text { Free electron gas of } \\
\text { noble metal forms } \\
\text { localized surface } \\
\text { plasmon (LSP) }\end{array}$ & $\begin{array}{l}\text { Acid black; } \\
\text { Acid brown }\end{array}$ & UV & $\begin{array}{l}\text { 97\% (Acid } \\
\text { black); } \\
\text { 85\% (Acid } \\
\text { brown); } \\
\text { magnetic } \\
\text { removal of } \\
\text { catalyst }\end{array}$ & {$[52]$} \\
\hline
\end{tabular}


Table 3. Cont.

\begin{tabular}{|c|c|c|c|c|c|c|}
\hline Morphology & Advantages & Mechanisms & Usage & Light & $\begin{array}{c}\text { Stability + } \\
\text { Reusability }\end{array}$ & References \\
\hline $\begin{array}{c}\mathrm{g}-\mathrm{C}_{3} \mathrm{~N}_{4} / \mathrm{Fe}_{3} \mathrm{O}_{4} / \mathrm{p}- \\
\mathrm{RuNP}\end{array}$ & $\begin{array}{c}\text { Simple and } \\
\text { convenient } \\
\text { (efficiency, energy, } \\
\text { and reusability), and } \\
\text { facile separation from } \\
\text { the reaction mixture }\end{array}$ & $\begin{array}{l}\mathrm{E}_{\mathrm{g}}=2.76 \mathrm{eV} \\
\cdot \mathrm{OH} \text {; radical is } \\
\text { responsible for the } \\
\text { reactions }\end{array}$ & $\begin{array}{l}\text { Congo red (CR); } \\
\text { Chlorazol black } \\
\text { (CB); } \\
\text { Evans blue (EB); } \\
\text { Reactive read } \\
\text { (RR) }\end{array}$ & $\begin{array}{l}\text { Visible; } \\
\text { LED; } \\
\text { Sunlight }\end{array}$ & $\begin{array}{c}85 \% \text { (CR); } \\
73 \% \text { (CB); } \\
65 \%(\mathrm{~EB}) ; \\
80 \%(\mathrm{RR}) ; \\
65-85 \% \\
\text { efficiency; } \\
95 \% \text { efficiency } \\
\text { after } 5 \text { cycles }\end{array}$ & [53] \\
\hline $\begin{array}{l}\mathrm{CoFe}_{2} \mathrm{O}_{4} / \mathrm{SrTiO}_{3} \\
\text { perovskite }\end{array}$ & $\begin{array}{l}\text { Efficient, stable, and } \\
\text { magnetic } \\
\text { photocatalyst; } \\
\text { easy separation from } \\
\text { water }\end{array}$ & $\begin{array}{c}\mathrm{N}: \mathrm{SrTiO}_{3} \\
\mathrm{E}_{\mathrm{g}}=2.58 \mathrm{eV} \\
\mathrm{CoFe}_{2} \mathrm{O}_{4} \\
\mathrm{Eg}=1.76 \mathrm{eV}\end{array}$ & $\begin{array}{l}\text { Acid brown; } \\
\text { Acid black }\end{array}$ & Visible & $\begin{array}{c}\text { Acid brown } \\
44 \% ; \\
\text { Acid black } 99 \%\end{array}$ & [54] \\
\hline $\begin{array}{c}\mathrm{Fe}_{3} \mathrm{O}_{4-}^{-} \\
\text {microsphere/ } \\
\text { polypyrrole-Ag }\end{array}$ & $\begin{array}{c}\text { Core-shell } \\
\text { morphology } \\
\mathrm{Fe}_{3} \mathrm{O}_{4} \text { as N-type } \\
\text { semiconductor; } \\
\text { Polypyrrole (PPY) as } \\
\text { p-type semiconductor }\end{array}$ & $\begin{array}{l}\text { The doped Ag } \\
\text { improve } \\
\text { transportation and } \\
\text { separation of } \\
\text { photo-induced } \\
\text { charges on the } \\
\text { surface interface; } \\
\text { Band gaps are } \\
\mathrm{E}_{\mathrm{g}}=\sim 2.5 \mathrm{eV} \text { for } \\
\text { nanocomposites of } \\
\text { conducting } \\
\text { polymer }\end{array}$ & $\begin{array}{l}\text { Methyl orange } \\
\text { (MO); } \\
\text { Orange II (OII) }\end{array}$ & UV & $\begin{array}{l}\text { 86.2\% MeO; } \\
80.4 \% \text { OII }\end{array}$ & [55] \\
\hline $\begin{array}{c}\mathrm{Li}_{2} \mathrm{~B}_{4} \mathrm{O}_{7} / \mathrm{LiBO}_{2} / \mathrm{Li}_{3} \mathrm{~B} \\
(\mathrm{LBO})\end{array}$ & $\begin{array}{c}\text { Strong photo } \\
\text { absorption; } \\
\text { Jhigh-efficiency charge } \\
\text { carrier separation; } \\
\text { uniform particle size; } \\
\text { Appropriate band gap }\end{array}$ & $\begin{array}{c}\text { Superoxide radicals } \\
\left(\cdot \mathrm{O}_{2}^{-}\right) \text {and holes } \\
\left(\mathrm{h}^{+}\right) \text {are the } \\
\text { prevailing active } \\
\text { species }\end{array}$ & Acid violet 7 & UV & $\begin{array}{l}91 \% \text { AV7; } \\
70 \% \text { TOC }\end{array}$ & [56] \\
\hline $\begin{array}{c}\mathrm{Ni}(\mathrm{OH})_{2} \\
\text { nanosheets } / \mathrm{ZnO} \\
\text { nanorods }\end{array}$ & $\begin{array}{l}\text { Well-crystallized } \mathrm{ZnO} ; \\
\text { poorly crystallized } \\
\mathrm{Ni}(\mathrm{OH})_{2} \cdot 0.75 \mathrm{H}_{2} \mathrm{O} ; \\
\text { absorbance edge } \\
\text { shifts to red }\end{array}$ & $\begin{array}{l}\text { Interface charge } \\
\text { transfer (IFCT) from } \\
\text { conducting band of } \\
\mathrm{ZnO} \text { to } \mathrm{Ni}(\mathrm{II}) \\
\text { heterojunction }\end{array}$ & $\begin{array}{c}\text { Rhodamine B; } \\
\text { CR; } \\
\text { MB; } \\
\text { MO }\end{array}$ & Visible & $82.6-98.4 \% \mathrm{MB}$ & [57] \\
\hline $\mathrm{ZrS}_{2}-\mathrm{ZnO}$ & $\begin{array}{l}\mathrm{ZrS}_{2} \text { has } \mathrm{E}_{\mathrm{g}}=1.68 \mathrm{eV} \\
\mathrm{The} \text { coexistence of } \\
\mathrm{ZrS}_{2} \text { increases the } \\
\text { absorbance of } \mathrm{ZnO} \text { in } \\
\text { the } \mathrm{UV} \text { region }\end{array}$ & $\begin{array}{c}\mathrm{e}^{-} \text {in the } \\
\text { conducting bands } \\
\text { of } \mathrm{ZrS}_{2} \text { and } \mathrm{ZnO} \\
\text { reduce } \mathrm{O}_{2} \text { to } \cdot \mathrm{O}_{2}^{-} \text {, } \\
\mathrm{h}^{+} \text {in valence band } \\
\text { of } \mathrm{ZnO} \text { oxidize } \mathrm{H}_{2} \mathrm{O} \\
\text { to } \cdot \mathrm{OH}\end{array}$ & $\begin{array}{l}\text { Naphthol blue } \\
\text { black (NBB) }\end{array}$ & UV & $\begin{array}{l}98.5 \% \text { Efficiency } \\
\text { after 4th run }\end{array}$ & [58] \\
\hline
\end{tabular}

Silver nanoparticles (AgNPs) were functionalized to nanocomposites by utilizing Portulaca Oleracea leave (PNL) aqueous extract as a reducing reagent. The nanocomposites are an important part of one-pot green and sustainable approaches for the photodegradation of reactive textile dyes. They also possess antibacterial and antidiabetic potentials [59].

Figure 4 indicates the interplay of two metal oxides in nanocomposites. The strategies of improving photocatalytic performance still lie in reducing the band gap and reducing electron/hole recombination rates. The nanocomposite of two metal oxides can benefit from the reduced band gap due to the heterojunctions. Another way to increase photocatalytic activity is to increase the light absorbance efficiency. One last interesting method is to include magnetic $\mathrm{Fe}_{3} \mathrm{O}_{4}$ for easy separation of the catalysts. 


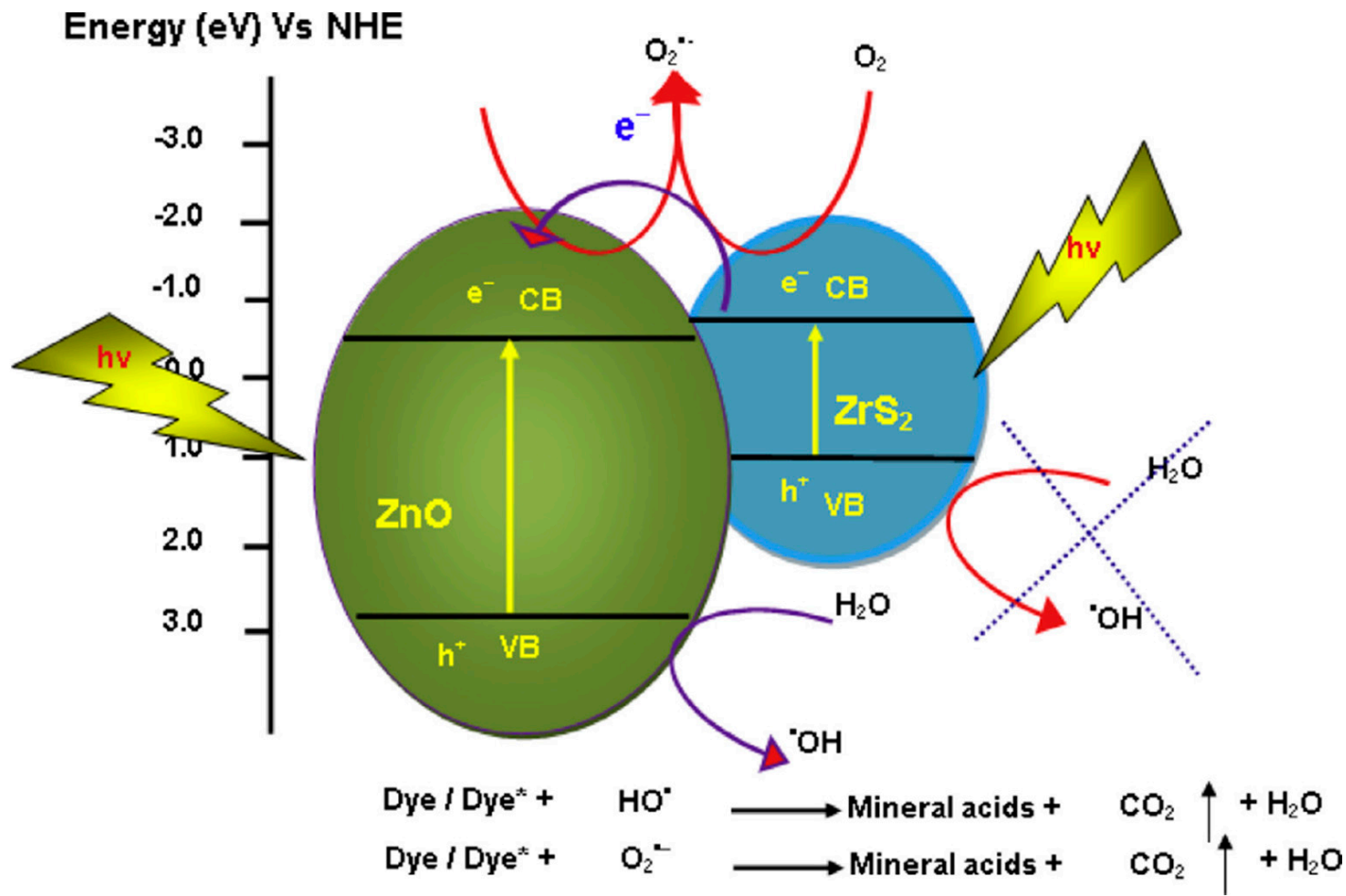

Figure 4. Photocatalytic mechanism for $\mathrm{ZnO} / \mathrm{ZrS}_{2}$ nanocomposite [58]. Reproduced with the permission of Separat. Purif. Tech.

\section{Polymer Nanocomposites Utilizing Azo Dyes}

\subsection{Photo-Control Machinery}

We mentioned the photo-switch properties of azo dyes and enhanced fluorescence through restricting photo-isomerization in Section 1. New exciting applications can be found at molecular, polymer, and nanocomposite levels.

One remarkable application at the molecular level comes from the development of photoswitchable anti-cancer drugs [60]. Recently Trauner and co-workers [61] developed an inhibitor of microtubules called photostatin (PST), which is an azobenzene derivative with four $\mathrm{OCH}_{3}$ groups and one $\cdot \mathrm{OH}$ group. Photostatins exposed to blue light are 250 times more cytotoxic than PSTs kept in the dark. Photostatins are "off" in the stable transform when kept in the dark and are "on" in the cis-form when put under blue light. Thus, the drugs can be safely applied in large doses globally and only activated locally in cancer tissues by shining blue light.

Azo dyes are an important moiety of shape-shifting polymers that can harvest sunlight energy $[62,63]$. Heteroaryl azo dyes, which replace one or both benzene rings of azo dyes by heteroaryl rings (such as pyridine, pyrimidine, pyrazole and indazole, imidazole etc.), have been explored as molecular photo-switches. Certain heteroaryl azos can exist in metastable cis-forms for anything from hundreds of picoseconds to more than 1000 days [64]. The chiral optical properties are demonstrated in polypeptides in helix formation and liquid crystal [65]. Among other interesting applications, the polypeptides are found to experience light-induced helix reversal after the azo dyes are bonded to polypeptides as sidechains. A linear polymer with azobenzene as a main chain component can act as a photo-induced motor in which two mechanical steps and two photo-induced steps are required in order for the motor to actuate [66]. Barrett and coworkers reviewed recent developments towards optical control of bio-interfaces. For example, Azo photo-switches could be incorporated into natural polymers thus influencing living systems, and photo-switchable soft azo dye materials could be employed to develop artificial muscles and light-powered soft robotics [67]. 
Diaz et al. developed biodegradable polymer/azo-dye film by the addition of carbon nanotubes and found that the maximum optical anisotropy was obtained $15^{\circ} \mathrm{C}$ below the glass transition temperature. The properties were interpreted as the interactions among disperse orange 3 (OD3), multi-walled carbon nanotubes (MWCNTs), and poly(lactic acid) (PLA) and the packing density of azo dyes into the polymer chain [68]. Georgiev et al. synthesized nanocomposite films of perylene bis azo-imides and showed that the nanocomposites had improved photo-responsiveness so that they can be used as visiblelight-activated molecular switches [69]. Zhang et al. prepared a photoisomerizable surface using an azo dye $/ \mathrm{TiO}_{2}$ nanocomposite film. The azo dye, para-methyl red, undergoes isomerization at room temperature on the $\mathrm{TiO}_{2}$ nanoparticle supports. They can be potentially used in solar cells [70].

\subsection{Nonlinear Optical Materials}

Raposo and coworkers synthesized donor-acceptor (DA) thienylpyrrole azo dyes by replacing one benzene ring of azo dye with thienylpyrrole ring, which could potentially be used as nonlinear optical materials in optical communications [71]. Churikov et al. reviewed the third-order nonlinear optical phenomena in azo dye polymers [72].

Liquid crystal photo-alignment of azo dyes was found to be different from previous ones such as photo-crosslinking, photo-degradation, and photo-isomerization. It can provide a controllable pretilt angle and strong anchoring energy of the liquid crystal cell, so it is very promising to use in the liquid crystal display (LCD) industry [73]. The azo dye, methyl red, dopes on the nematic liquid crystal (LC) pentycyanobipenyl (5CB), giving rise to colossal nonlinear or to light-induced anchoring and memory effects, so the methyl-red-doped liquid crystals have a potential for photonic applications [74,75].

\subsection{Light Aligning Materials}

The light aligning properties of azo dyes can be explored together with the selfassembly method to synthesize liquid crystals.

Kumar and coworkers employed in situ self-assembled dual-wavelength photoalignment to obtain highly stable pre-tilted homeotropic alignment of liquid crystal [76]. Kundu et al. demonstrated a reliable, practical, and cost-effective "one-pot approach" for a homeotropic alignment of nematic liquid crystals that is achieved by photochromic trans- to cis-isomerization of the azo dye doped in a nematic host [77]. Yeung and coworkers described the formation kinetics and related optical properties of a self-assembled monolayer [78].

The common situation for the self-assembly of azobenzene (AB) derivatives is to associate them with polymers to take advantage of the interactions between the phenyl rings of $A B$ derivatives. The interactions between $A B$ derivatives can be London force or dipole/dipole interactions. The aggregation patterns can be J- and H-types that separately represent head-to-tail and one-on-top-of-the-other arrangements. Depending on the angle $\theta$ (Scheme 1), the maximum absorption in UV-vis spectra of the assembled AB derivatives demonstrated blue shift or red shift separately for $\mathrm{H}$ - and J-aggregations in comparison with free $A B$ derivatives. This phenomenon was clearly explained by the following equation [79]:

$$
\Delta \varepsilon=2 \mathrm{M}^{2}\left(1-3 \cos ^{2} \theta\right) / r^{3}
$$

whereas $\mathrm{M}$ is the dipole moment, $r$ is the center-to-center distance between molecules, and $\theta$ is defined in Scheme 1.

It is clear that (1) when $\theta=54.7^{\circ}$, no splitting (change) occurs in the maximum absorbance peak; (2) when $\theta>54.7^{\circ}$, there is a blue-shift; and (3) when $\theta<54.7^{\circ}$, there is a red-shift.

Tong and co-workers synthesized the azobenzene-containing diblock copolymers through the atom transfer radical polymerization technique [80]. The percentages of three different aggregation states among azobenzene units $(\mathrm{H}, \mathrm{J}$, and free) are estimated at $25{ }^{\circ} \mathrm{C}$ and $80^{\circ} \mathrm{C}$. With the reference to the photochemical LC-isotropic phase transition, 
the authors pictured that the anchoring (ordering) at the interface might slow down the propagation of the perturbation of cis isomers that were responsible for the destabilization of the ordered LC phase.

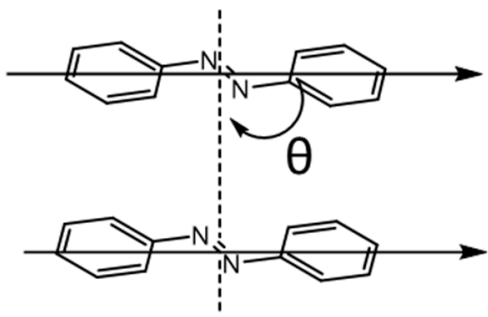

H-aggregation

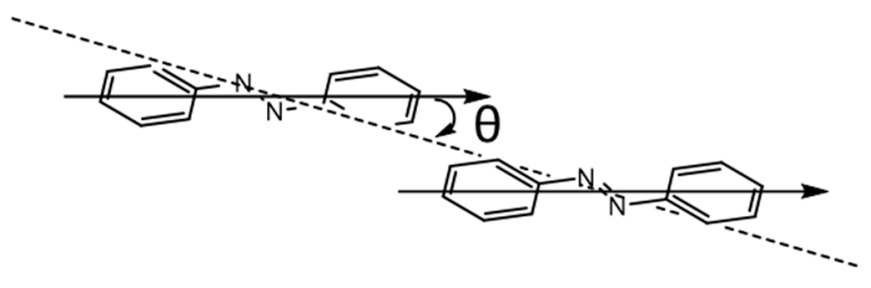

J-aggregation

Scheme 1. The H- and J-aggregations and related geometrical parameters for a azobenzene dimer.

Menzel and co-workers studied Langmuir-Blodgett (LB) films of poly(5-(2-(4-((4hexylphenyl)azo)phenoxy)ethyl) L-glutamate) (P2) and poly(5-(6-(4-((4-hexylphenyl)azo) phenoxy)hexyl) L-glutamate) (P6) polymers with a stiff backbone and flexible sidechains ("hairy rods") [81]. The original LB structure, which is characterized by deformed "hairy rods" arranged in bilayers, is destroyed upon photoisomerization or annealing. The sidechains relax to a more symmetrical distribution around the main chain helix. Furthermore, the aggregation of the chromophores as well as their orientation in respect to the main chain helix is changed. The polymers with different spacers (P2, P4, and P6) confirmed that the supramolecular order of LB films of these thermotropic polypeptides established due to the fact of irradiation and/or annealing is determined by the enthalpic stability of the mesophase and the dynamic properties of the polymers [82].

Bilayer and liquid crystal situations show significantly enhanced fluorescence for azobenzene derivatives. Shimomura and Kunitake reported the strong fluorescence enhancement when the azobenzene-containing amphiphiles were included in aqueous bilayer system, which was explained by head-to-tail J-like aggregation with $\pi-\pi^{*}$ characteristics [83]. Tamai et al. reported the fluorescence properties of an azobenzene liquid crystal, $4,4^{\prime}$-dioctyloxyazobenzene (8AB8), as a function of temperature by picosecond singlephoton timing spectroscopy. They assigned the fluorescence peak at $\sim 590 \mathrm{~nm}$ to the $S_{1}$ fluorescence of a J-like aggregate of 8AB8 and assigned a weaker peak at $\sim 420 \mathrm{~nm}$ to $\pi-\pi^{*}$ fluorescence [84].

\section{Self-Assembly Method to Introduce Azo Dyes into Polymer Nanocomposites}

The self-assembly method is an efficient way to introduce azo dyes into nanocomposites. Besides the photo-alignment approaches, two major properties are commonly employed: (1) London forces or dipole/dipole interactions between azo dyes; (2) electrostatic interactions for which azobenzene (AB) derivatives could have ionic substituent (or hydrogen bond-forming substituent) or polymers are Zwitterionic polymers.

He et al. prepared NiFe-layered double hydroxide-based azobenzene composite films through the self-assembly method, and the composite films have good stability and a high acid-base gas sensitivity [85]. Zhuang et al. obtained nanoaggregated dispersed red 1-functionalized poly(N-vinylcarbazole) film via solution-phase assembly, and the device showed an ON/OFF current ratio of $10^{5}$ [86].

Ionic self-assembly (ISA) strategy was used as a supramolecular approach to easily synthesize optically anisotropic materials in which ethyl orange azo dye was complexed with double-tailed ammonium surfactants [87]. The azobenzene containing Zwitterionic polymers can self-assemble into photo- and thermal-responsive polymers that are water soluble and applicable in biological systems [88]. The self-assembly of multilayer diazonium resin, J-acid, photochromic spiroxazine, and poly-(sodium-4-styrene)sulfonate (PSS) can be conducted. The materials can potentially be used in data recording, optical switching, 
displays, and non-linear optics [89]. Holographic surface relief gratings (SRGs) were fabricated on composite films assembled by electrostatic layer-by-layer (LbL) deposition of a polyelectrolyte, poly(dimethyl diallylammonium chloride) (PDAC), and an azo dye, Congo red (CR). This approach provides a methodology to fabricate SRGs for optical information storage [90].

Polymethacrylate containing azopyridine side chain (PAzPy) forms diblock copolymer with polystyrene, and the azopyridine moiety enabled the easy self-assembly to effectively load zinc-tetraphenylporphyrin (ZnTPP) inside microdomains of PAzPy block [91]. Azo dye chromotrope-2R $(\mathrm{CH} 2 \mathrm{R})$ and polycation (poly(allyamine hydrochloride) $(\mathrm{PAH})$ were successfully deposited onto solid surfaces as a film through layer-by-layer electrostatic self-assembly. In LbL films, the more closure association of dye molecules causes the aggregation of dye molecules, which is reflected in their absorption and steady-state fluorescence emission spectra when compared to those of pure solutions [92]. Hydrogen bonds were employed to synthesize supramolecular azopolymer-a multilayered composite through alternative stacking. The optical birefringence was observed under two-photon excitation [93]. The layer-by-layer self-assembly (LbL) technique was used to obtain poly(pphenylenevinylene)/Congo red thin film. The LbL PPV/CR film thermally converted at $110^{\circ} \mathrm{C}$ and azo dye Congo red experienced a considerable decrease in degradation in the polymer matrix [94]. The electrostatic interactions were used to obtain self-assembled nanoparticles from linear flexible polyelectrolytes and an ionic photo-isomerizable acid yellow 38 (AY-38). The UV light exposure triggers a size change from $R_{h}=94 \mathrm{~nm}$ to $R_{h}=62 \mathrm{~nm}$ for a sample with a charge ratio of $I_{\text {charge }}=0.7$ [95].

The following is a typical application of self-assembly methods to incorporate azo dye into co-polymers. Jin et al. synthesized the copolymers poly(acrylonitrile)-stat-poly(4vinyl-pyridine) (PAN-stat-P4VP) from reversible addition-fragmentation chain-transfer (RAFT) polymerization (Scheme 2) [96,97].
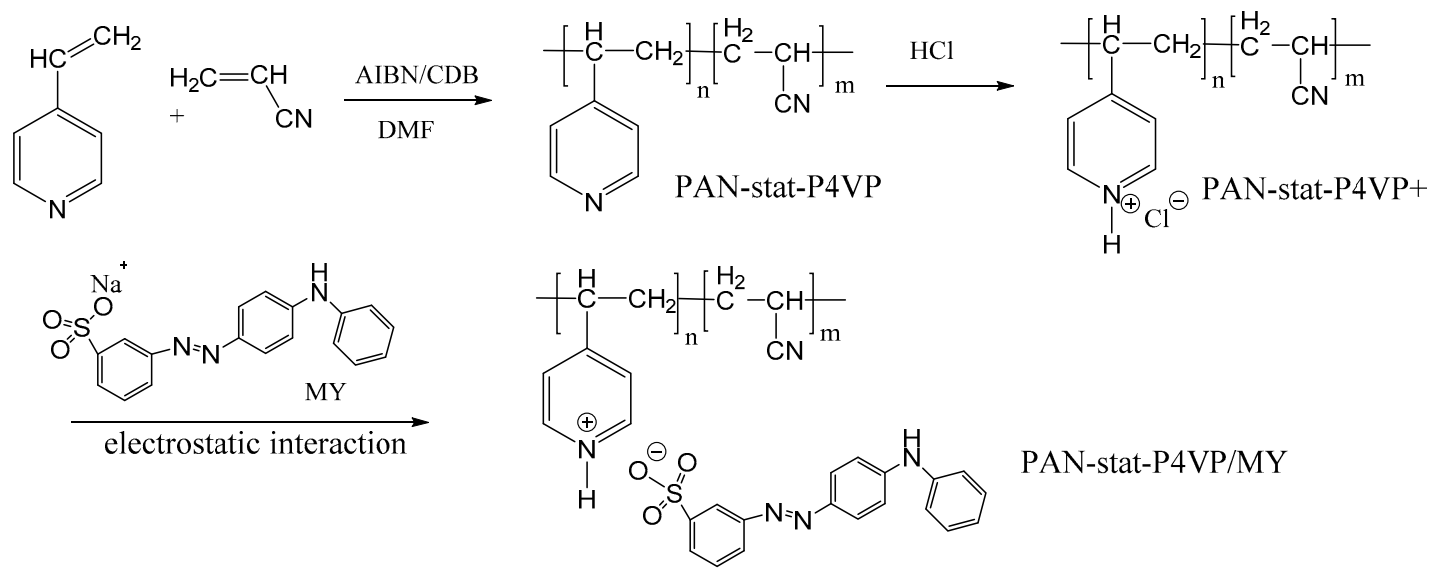

Scheme 2. Synthetic routes for poly(acrylonitrile)-stat-poly(4-vinyl-pyridine) (PAN-stat-P4VP) copolymers and PAN-statP4VP/MY complexes. Accronyms: AIBN, azobisisobutyronitrile; CDB, cumyl dithiobenzoate; DMF, dimethylformamide; and MY, metanil yellow.

The formed PAN-stat-P4VP/MY complexes were identified to be nanospheres using transmission electron microscopy (TEM). The size of the hollow nanospheres was homogeneous and could be conveniently controlled by varying molar ratios of the copolymers to $\mathrm{MY}$ and molar ratios of monomers of the copolymers. The formation process is illustrated in Scheme 3.

Using a similar procedure, Jin and coworkers synthesized poly (methyl methacrylatestat-poly (4-vinylpyridine)) copolymer (PMMA-stat-P4VP). The PMMA-stat-P4VP associates with 4-phenylazophenol by hydrogen bonding and by forming nanospheres. Under the irritation of a linearly polarized $\mathrm{Ar}^{+}$laser beam, the nanospheres underwent a striking deformation of shapes $[98,99]$. 


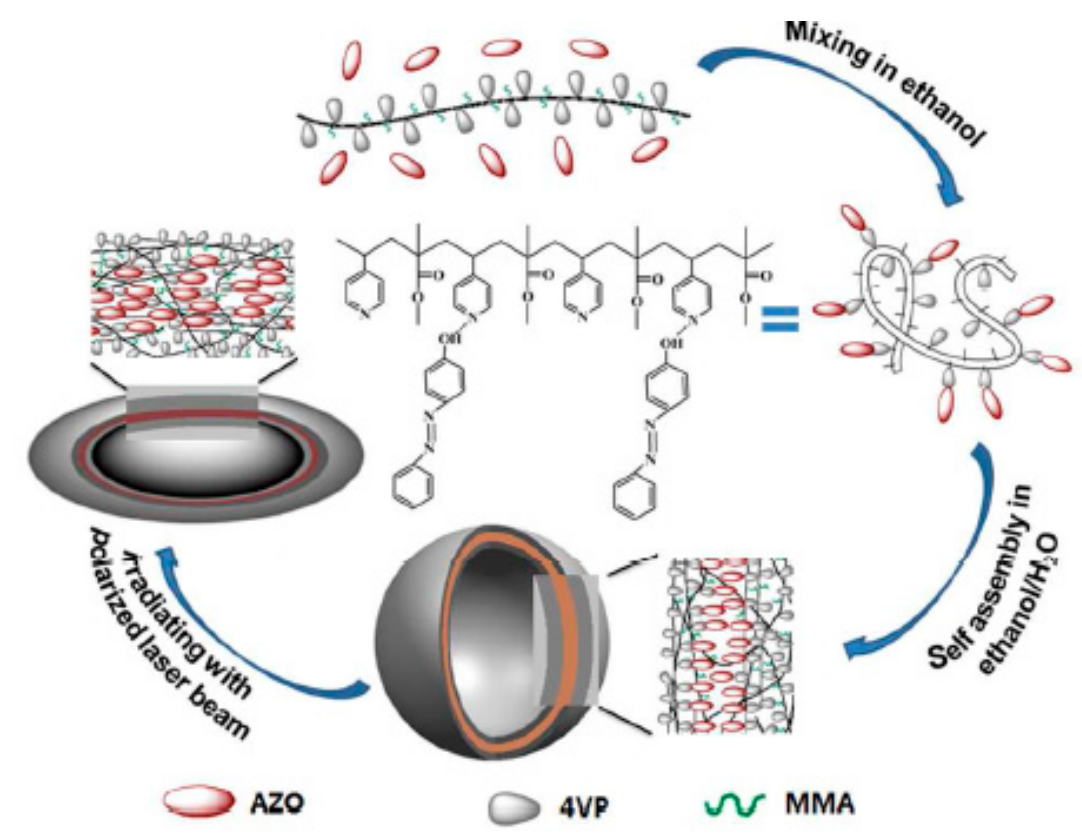

Scheme 3. Schematic illustration for the formation process of poly (methyl methacrylate-statpoly (4-vinylpyridine)) (PMMA-stat-P4VP)/AZO hollow nanospheres and elongated hollow nanospheres [98]. AZO denotes azo dye molecules. Reproduced with the permission of RSC Advance.

\section{Conclusions and Outlook}

Polymer nanocomposites for azo-dye degradation or removal could be made from a variety of resources such as natural polymers (chitosan, fly ash, and kaolin), synthesized polymers (exfoliated h-BN, hydrogel, etc.), and the oxides of $\mathrm{Al}, \mathrm{Au}, \mathrm{Bi}, \mathrm{Fe}, \mathrm{Li}, \mathrm{Ni}$, and $\mathrm{Zr}$. The $\mathrm{TiO}_{2}$-based nanocomposites are among the most explored and widely used photocatalysts for the degradation of azo dyes in wastewaters and textile effluents. These nanocomposites have better photocatalytic efficiency through two considerations: (1) reducing the hole/electron recombination rate by stabilizing the excited electron in the conducting band, which is achieved by forming $\mathrm{TiO}_{2}$ nanocomposites with graphene, graphene oxide, hexagonal boron nitride (h-BN), metal nanoparticles, or by doping $\mathrm{TiO}_{2}$-nanocomposites; (2) decreasing the band energy of semiconductors by forming nanocomposites between $\mathrm{TiO}_{2}$ and other oxides or conducting polymers. Future research in nanocomposite catalysts may include the followings: (1) developing novel nanostructure photocatalysts that show strong photoabsorption efficiency, which will lead to the increase in photocatalytic efficiency; (2) purposefully introducing polymer materials to reduce or eliminate the electron-hole recombination in nanostructured photocatalysts; (3) using economical and less hazardous nanocomposites catalysts for the degradation of azo dyes, which can avoid further contamination of water.

The photo-induced isomerization has meaningful applications in biological systems, such as artificial muscles, and in technical fields such as memory storage and liquid crystal display. Heteroaryl azo dyes show remarkable shifts in photo-induced isomerization, which might be applied in biological and technical fields in place of azo dyes.

The photoinduced properties are different at molecular, polymer, and nanocomposite levels. An overview from three levels would inspire us to learn from the property changes due to the size and dimension increase and then exploit these properties. For example, the photoisomerization will be hindered when the azo dyes are restrained in polymer materials, but nanocomposites could incorporate azo dyes inside the matrix of supporting materials. Liquid crystal and optical control of bio-interfaces are other examples to properly exploit the azo dye properties. The azo dyes will definitely be outstanding if we properly put them into use together with other compounds. Azo dyes unveil their many faces such as hazards from textile industry, anti-cancer and anti-bacterial drugs, photo-control 
switches, and memory storage media. More importantly, they lend hands for human beings to interact with the world and harvest solar energies. Azo dyes have been directly incorporated into polymer nanocomposites promising for activated molecular switch, optical recording media, and solar cells. The self-assembly method has shown a promising future in synthesizing polymer nanocomposites containing azo dyes.

Due to the special optical properties of azo-dye molecules, we expect that more novel polymer nanocomposites containing azo dyes will be designed and synthesized to meet the needs of special applications such as optical actuation and controlled drug delivery. Particularly, the self-assembly approach can be applied for the fabrication of these polymer composites. Along this direction, extensive research efforts may be focused on the precise control of the photo-induced properties of azo-dye-based polymer nanocomposites.

Funding: This research was funded by NSF-MRI 1827839. D.X. also acknowledges the support of endowed Buckman Chair award from the University of New Haven.

Institutional Review Board Statement: Not applicable.

Informed Consent Statement: Not applicable.

Data Availability Statement: Not applicable.

Conflicts of Interest: The authors declare no conflict of interest.

\section{References}

1. IARC Working Group on the Evaluation of Carcinogenic Risks to Humans. Some Aromatic Amines, Organic Dyes, and Related Exposures. Lyon (FR): International Agency for Research on Cancer; 2010. (IARC Monographs on the Evaluation of Carcinogenic Risks to Humans, No. 99. Available online: https:/ / www.ncbi.nlm.nih.gov/books/NBK385442/ (accessed on 24 March 2021).

2. Weglarz-Tomczak, E.; Gorecki, L. Azo dyes-Biological activity and synthetic strategy. Chemik 2012, 66, 1298-1307.

3. Price, R. Aspects of the chemistry of metal complex dyes. Chimia 1974, 28, 221-231.

4. Rauf, M.A.; Hisaindee, S.; Saleh, N. Spectroscopic studies of keto-enol tautomeric equilibrium of azo dyes. RSC Adv. 2015, 5, 18097-18110. [CrossRef]

5. Lesch, J.E. The First Miracle Drugs: How the Sulfa Drugs Transformed Medicine; Chapter 3: Prontosil; Oxford University Press: Oxford, UK, 2007; p. 51.

6. Chung, K.-T. Azo dyes and human health: A review. J. Environ. Sci. Health Part C 2016, 34, 33-261. [CrossRef] [PubMed]

7. Bafana, A.; Devi, S.S.; Chakrabarti, T. Azo dyes: Past, present and the future. Environ. Rev. 2011, 19, 350-370. [CrossRef]

8. Fatima, M.; Farooq, R.; Lindstrom, R.W.; Saeed, M. A review on biocatalytic decomposition of azo dyes and electrons recovery. J. Liq. 2017, 246, 275-281. [CrossRef]

9. Singh, R.L.; Singh, P.K.; Singh, R.P. Enzymatic decolourization and degradation of azo dyes-A review. Int. Biodeterior. Biodegrad. 2015, 104, 21-31. [CrossRef]

10. Kishor, R.; Purchase, D.; Saratale, G.D.; Saratale, R.G.; Ferreira, L.F.R.; Bilal, M.; Chandra, R.; Bharagava, R.N. Ecotoxicological and health concerns of persistent coloring pollutants of textile industry wastewater and treatment approaches for environmental safety. J. Chem. Environ. Eng. 2021, 9, 105012. [CrossRef]

11. Hartley, G.S. The cis-form of azobenzene. Nature 1937, 140, 281. [CrossRef]

12. Fischer, E.; Frankel, M.; Wolovslcy, R. Wavelength Dependence of Photoisomerization Equilibria in Azocompounds. J. Chem. Phys. 1955, 23, 1367. [CrossRef]

13. Bortolus, P.; Monti, S. Cis-Trans Photoisomerization of Azobenzene. Solvent and Triplet Donor Effects. J. Phys. Chem. 1979, 83, 648-652. [CrossRef]

14. Loper, G.L.; Dorer, F.H. Primary Processes in the Photochemistry of 1 -Pyrazoline. J. Am. Amer. Chem. Soc. 1973, 95, 20-26. [CrossRef]

15. Solomon, B.S.; Thomas, T.F.; Steel, C. Primary Processes in the Photochemistry of Bicyclic Azo Compounds. J. Am. Chem. Soc. 1968, 90, 2249-2258. [CrossRef]

16. Bandara, H.M.D.; Friss, T.R.; Enriquez, M.M.; Isley, W.; Incarvito, C.; Frank, H.A.; Gascon, J.; Burdette, S.C. Proof for the Concerted Inversion Mechanism in the transfcis Isomerization of Azobenzene Using Hydrogen Bonding To Induce Isomer Locking. J. Org. Chem. 2010, 75, 4817-4827. [CrossRef] [PubMed]

17. Yoshino, J.; Kano, N.; Kawashima, T. Synthesis of the most intensely fluorescent azobenzene by utilizing the B-N interaction. Chem. Commun. 2007, 6, 559-561. [CrossRef] [PubMed]

18. Zhu, H.-Y.; Xiao, L.; Jiang, R.; Zeng, G.-M.; Liu, L. Efficient decolorization of azo-dye solution by visible light-induced photocatalytic process using $\mathrm{SnO}_{2} / \mathrm{ZnO}$ heterojunction immobilized in Chitosan matrix. Chem. Eng. J. 2011, 172, 746-753. [CrossRef]

19. Bhatt, R.; Ageetha, V.; Rathod, S.B.; Padmaja, P. Self-assembled chitosan-zirconium phosphate nanostructures for adsorption of chromium and degradation of dyes. Carbohydr. Polym. 2019, 208, 441-450. [CrossRef] [PubMed] 
20. Sathiyavimal, S.; Vasantharaj, S.; Kaliannan, T.; Pugazhendhi, A. Eco-biocompatibility of chitosan coated biosynthesized copper oxide nanocompoistes for enhanced industrial (Azo) dye removal from aqueous solution and antibacterial properties. Carbohydr. Polym. 2020, 241, 116243. [CrossRef] [PubMed]

21. Kafil, M.; Nasab, B.; Moazed, H.; Jokiniemi, J.; Laehde, A.; Bhatnagar, A. Efficient removal of azo dyes from water with chitosan/carbon nanoflower as a novel nanocomposite synthesized by pyrolysis technique. Desalin. Water Treat. 2019, 142, 308-320. [CrossRef]

22. Banerjee, P.; Barman, S.R.; Mukhopadhayay, A.; Das, P. Ultrasound assisted mixed azo dye adsorption by chitosan-graphene oxide nanocomposite. Chem. Eng. Res. Des. 2017, 117, 43-56. [CrossRef]

23. Mohagheghian, A.; Vahidi-Kolur, R.; Pourmohseni, M.; Yang, J.-K.; Shirzad-Siboni, M. Application of Scallop shell-Fe ${ }_{3} \mathrm{O}_{4}$ nano-composite for the removal of azo dye from aqueous solutions. Water Air Soil Pollut. 2015, 226, 1-16. [CrossRef]

24. Dey, S.C.; Moztahida, M.; Sarker, M.; Ashaduzzaman, M.; Shamsuddin, S.M. pH-triggered interfacial interaction of kaolinite/chitosan nanocomposites with anionic azo dye. J. Compos. Sci. 2019, 3, 39. [CrossRef]

25. Mohagheghian, A.; Pourmohseni, M.; Vahidi-Kolur, R.; Yang, J.-K.; Shirzad-Siboni, M. Application of kaolin-Fe $\mathrm{O}_{4}$ nanocomposite for the removal of azo dye from aqueous solutions. Desalin. Water Treat. 2017, 58, 308-319. [CrossRef]

26. Stengl, V.; Henych, J.; Slusna, M. h-BN-TiO 2 nanocomposite for photocatalytic applications. J. Nanomater. 2016, $2016,4580516$. [CrossRef]

27. Sharma, A.K.; Lee, B.-K. Surfactant-aided sol-gel synthesis of $\mathrm{TiO}_{2}-\mathrm{MgO}$ nanocomposite and their photocatalytic azo dye degradation activity. J. Compos. Mater. 2020, 54, 1561-1570. [CrossRef]

28. Karimzadeh, S.; Bahrami, K. Role of L-cysteine and CdS as promoted agents in photocatalytic activity of $\mathrm{TiO}_{2}$ nanocomposite. J. Environ. Chem. Eng. 2020. ahead of print.

29. Katancic, Z.; Gavran, I.; Smolkovic, J.; Hrnjak-Murgic, Z. Fly ash supported photocatalytic nanocomposite poly(3,4ethylenedioxythiophene) $/ \mathrm{TiO}_{2}$ for azo dye removal under simulated solar irradiation. J. Appl. Polym. Sci. 2018, 135,46316 . [CrossRef]

30. Zangeneh, H.; Farhadian, M.; Zinatizadeh, A.A. N(Urea) and C-N (L-Asparagine) doped $\mathrm{TiO}_{2}-\mathrm{CuO}$ nanocomposites: Fabrication, characterization and photodegradation of direct red 16. J. Environ. Chem. Eng. 2020, 8, 103639. [CrossRef]

31. Ghanbari, S.; Givianrad, M.H.; Aberoomand, A.P. Synthesis and characterization of visible light driven N-Fe-codoped $\mathrm{TiO}_{2} / \mathrm{SiO}_{2}$ for simultaneous photoremoval of $\mathrm{Cr}(\mathrm{VI})$ and azo dyes in a novel fixed bed continuous flow photoreactor. Can. J. Chem. Eng. 2020, 98, 705-716. [CrossRef]

32. Barahimi, V.; Moghimi, H.; Taheri, R.A. $\mathrm{Cu}$ doped $\mathrm{TiO}_{2}-\mathrm{Bi}_{2} \mathrm{O}_{3}$ nanocomposite for degradation of azo dye in aqueous solution: Process modeling and optimization using central composite design. J. Environ. Chem. Eng. 2019, 7, 103078. [CrossRef]

33. Jorfi, S.; Mirali, S.; Mostoufi, A.; Ahmadi, M. Visible light photocatalytic degradation of azo dye and a real texile waste water using $\mathrm{Mn}, \mathrm{Mo}, \mathrm{La} / \mathrm{TiO}_{2} / \mathrm{AC}$ nanocomposite. Chem. Biochem. Eng. Q. 2018, 32, 215-227. [CrossRef]

34. Feng, J.; Wong, R.S.K.; Hu, X.; Yue, P.L. Discoloration and mineralization of orange II by using $\mathrm{Fe}^{3+}$-doped $\mathrm{TiO}_{2}$ and bentonite clay-based Fe nanocatalysts. Catal. Today 2004, 98, 441-446. [CrossRef]

35. Janitarbar-Darzi, S.; Mahjoub, A.R. Investigation of phase transformations and phtocatalystic properties of sol-gel prepared nanostructured $\mathrm{ZnO} / \mathrm{TiO}_{2}$ composite. J. Alloys Compd. 2009, 486, 805-808. [CrossRef]

36. Aquino, S.F.; Lacerda, C.A.; Ribeiro, D.R. Use of ferrites encapsulated with titanium dioxide for photodegradation of azo dyes and color removal of textile effluents. Environ. Eng. Sci. 2010, 27, 1049-1059. [CrossRef]

37. Alzahrani, E. Photodegradation of binary azo dyes using core-shell $\mathrm{Fe}_{3} \mathrm{O}_{4} / \mathrm{SiO}_{2} / \mathrm{TiO}_{2}$ nanospheres. Am. J. Anal. Chem. 2017, 8, 95-115. [CrossRef]

38. Lucic, M.; Milosavljevic, N.; Radetic, M.; Saponjic, Z.; Radoicic, M.; Kalagasidis, M. The potential application of TiO $2 /$ hydrogel nanocomposite for removal of various textile azo dyes. Sep. Purif. Technol. 2014, 122, 206-216. [CrossRef]

39. Bahram, M.; Salami, S.; Moghtader, M.; Moghadam, P.N.; Fareghi, A.R.; Rasouli, M.; Salimpour, S. Photocatalytic degradation of anionic azo dyes acid orange 7 and acid red 88 in aqueous solutions using $\mathrm{TiO}_{2}$-containing hydrogel. Anal. Bioanal. Chem. 2017, 4, 53-63.

40. Guo, N.; Liang, Y.; Lan, S.; Liu, L.; Ji, G.; Gan, S.; Zou, H.; Xu, X. Uniform $\mathrm{TiO}_{2}-\mathrm{SiO}_{2}$ hollow nanoshperes: Synthesis, charaterization and enhanced adsorption-photodegradation of azo dyes and phenol. Appl. Surf. Sci. 2014, 305, 562-574. [CrossRef]

41. Nilchi, A.; Janitabar-Darzi, S.; Rasouli-Garmarodi, S. Sol-gel preparation of nanoscale $\mathrm{TiO}_{2} / \mathrm{SiO}_{2}$ composite for eliminating con red azo dye. Mater. Sci. Appl. 2011, 2, 476-480.

42. Ayati, A.; Ahmadpour, A.; Bamoharram, F.F.; Tanhaei, B.; Manttari, M.; Lahtinen, M.; Sillanpaa, M. Novel Au NPs/preyssler acid $/ \mathrm{TiO}_{2}$ nanocomposite for the photocatalytic removal of azo dye. Sep. Purif. Technol. 2014, 133, 415-420. [CrossRef]

43. An, L.; Wang, G.; Cheng, Y.; Zhao, L.; Gao, F.; Tian, Y. Ultrasonic-assisted synthesis of visible-light-driven $\mathrm{TiO}_{2} / \mathrm{Bi}_{2} \mathrm{O}_{3}$ nanocomposite photocatalysts: Characterization, properties and azo dye removal application. Res. Chem. Intermed. 2015, 41, 7449-7461. [CrossRef]

44. Rosu, M.-C.; Socaci, C.; Floare-Avram, V.; Borodi, G.; Pogacean, F.; Coros, M.; Magerusan, L.; Pruneanu, S. Photocatalytic performance of graphene/ $\mathrm{TiO}_{2}-\mathrm{Ag}$ composites on amaranth dye degradation. Mater. Chem. Phys. 2016, 179, 232-241. [CrossRef]

45. Ghalebizade, M.; Ayati, B. Solar photoelectrocatalytic degradation of acid orange 7 with $\mathrm{ZnO} / \mathrm{TiO}_{2}$ nanocomposites coated on stainless steel electrode. Process Saf. Environ. Prot. 2016, 103, 192-202. [CrossRef]

46. Yu, A.; Lu, G.Q.M.; Drennan, J.; Gentle, I.R. Tubular titania nanostructures via layer-by-layer self-assembly. Adv. Funct. Mater. 2007, 17, 2600-2605. [CrossRef] 
47. Latifi, A.M.; Mirzaei, M.; Mousavi-Kamazani, M.; Zarghami, Z. Rice-like Ag/ $\mathrm{Al}_{2} \mathrm{O}_{3}$ nanocomposites preparation from $\mathrm{AlOOH}$ nanostructures synthesized via a facile hydrothermal route for azo dyes photocatalytic degradation and $\mathrm{Pd}^{2+}$ adsorption. J. Mater. Sci. Mater. Electron. 2018, 29, 10234-10245. [CrossRef]

48. Rohani, N.; Bamoharram, F.F.; Marijani, A.; Heravi, M.M. Gold nanoparticles Wells-Dawson heteropolyacid nanocomposite film as an effective nanocatalyst in photocatalytic removal of azo dyes from wastewaters. J. Nanostruct. Chem. 2017, 7, 171-178. [CrossRef]

49. Najafian, H.; Manteghi, F.; Beshkar, F.; Salavati-Niasari, M. Fabrication of nanocomposite photocatalyst $\mathrm{CuBi}_{2} \mathrm{O}_{4} / \mathrm{Bi}_{3} \mathrm{ClO}_{4}$ for removal of acid brown 14 as water pollutant under visible light. J. Hazard. Mater. 2019, 361, 210-220. [CrossRef] [PubMed]

50. D'Angelo, D.; Filice, S.; Scarangella, A.; Iannazzo, D.; Compagnini, G.; Scalese, S. $\mathrm{Bi}_{2} \mathrm{O}_{3} /$ Nexar polymer nanocomposite memberanes for azo dyes removal by UV-vis or visible light irradiation. Catal. Today 2019, 321, 158-163. [CrossRef]

51. Najafian, H.; Manteghi, F.; Beshkar, F.; Salavati-Niasari, M. Enhanced photocatalytic activity of a novel $\mathrm{NiO}_{2} \mathrm{Bi}_{2} \mathrm{O}_{3} / \mathrm{Bi}_{3} \mathrm{ClO}_{4}$ nanocomposite for the degradation of azo dye pollutants under visible light irradiation. Sep. Purif. Technol. 2019, $209,6-17$. [CrossRef]

52. Khaghani, S.; Ghanbari, D.; Khaghani, S. Green synthesis of iron oxide-palladium nanocomposites by pepper extract and its application in removing of colored pollutants from water. J. Nanostruct. 2017, 7, 175-182. [CrossRef]

53. Sahoo, A.; Patra, S. A magnetically separable and recyclable $g-\mathrm{C}_{3} \mathrm{~N}_{4} / \mathrm{Fe}_{3} \mathrm{O}_{4}$ / porous ruthenium nanocatalyst for photocatalytic degradation of water-soluable aromatic amines and azo dyes. RSC Adv. 2020, 10, 6043-6051. [CrossRef]

54. Eskandari, N.; Nabiyouni, G.; Masoumi, S.; Ghanbari, D. Preparation of a new magnetic and photocatalyst $\mathrm{CoFe}_{2} \mathrm{O}_{4}-\mathrm{SrTiO}_{3}$ perovskite nanocomposite for photo-degradation of toxic dyes under short time visible irradiation. Compos. Part B: Eng. 2019, 176, 107343. [CrossRef]

55. Chen, Y.; Gao, F.; An, L.; Li, X.; Wang, G. Different combinations of $\mathrm{Fe}_{3} \mathrm{O}_{4}$ microshere, polypyrrole and silver as core-shell nanocomposites for adsorption and photocatalytic application. Adv. Powder Technol. 2014, 25, 1600-1607. [CrossRef]

56. Ranjeh, M.; Beshkar, F.; Salavati-Niasari, M. Sol-gel synthesis of novel Li-based boron oxides nanocomposite for photodegradation of azo-dye pollutant under UV light irradiation. Compos. Part B: Eng. 2019, 172, 33-40. [CrossRef]

57. Cai, X.; Cai, Y.; Liu, Y.; Deng, S.; Wang, Y.; Wang, Y.; Djerdj, I. Enhanced photocatalytic degradation properties of Ni(OH) 2 nanosheets / $\mathrm{ZnO}$ nanorods composites for azo dyes under visible-light irradiation. Ceram. Int. 2014, 40, 57-65. [CrossRef]

58. Krishnakumar, B.; Imae, T.; Miras, J.; Esquena, J. Synthesis and azo dye photodegradation activity of $\mathrm{ZrS}_{2}-\mathrm{ZnO}_{\mathrm{nano}} \mathrm{composites}$ Sep. Purif. Technol. 2014, 132, 281-288. [CrossRef]

59. Saratale, G.D.; Saratale, R.G.; Cho, S.-K.; Ghodake, G.; Bharagava, R.N.; Park, Y.; Mulla, S.I.; Kim, D.-S.; Kadam, A.; Nair, S.; et al. Investigation of photocatalytic degradation of reactive textile dyes by Portulaca Oleracea-Functionalized silver nanocomposites and exploration of their antibacterial and antidiabetic potentials. J. Alloys Compd. 2020, 833, 155083. [CrossRef]

60. Sanderson, K. Lighting the way to more targeted treatments. C E News 2018, 2, 25-27.

61. Borowiak, M.; Nahaboo, W.; Reynders, M.; Nekolla, K.; Jalinot, P.; Hasserodt, J.; Rehberg, M.; Delattre, M.; Zahler, S.; Vollmar, A.; et al. Photoswitchable Inhibitors of Microtubule Dynamics Optically Control Mitosis and Cell Death. Cell 2015, 162, 403-411. [CrossRef] [PubMed]

62. Yamada, M.; Kondo, M.; Mamiya, J.; Yu, Y.; Kinoshita, M.; Barrett, C.J.; Ikeda, T. Photomobile Polymer Materials: Towards LightDriven Plastic Motors. Angew. Chem. Int. Ed. 2008, 47, 4986-4988. [CrossRef] [PubMed]

63. Bushuyev, O.S.; Aizawa, M.; Shishido, A.; Barrett, C.J. Shape-Shifting Azo Dye Polymers: Towards Sunlight-Driven Molecular Devices. Macromol. Rapid Commun. 2018, 39, 1700253. [CrossRef] [PubMed]

64. Crespi, S.; Simeth, N.A.; Konig, B. Heteroaryl azo dyes as molecular photoswitches. Nat. Rev. Chem. 2019, 3, 133-146. [CrossRef]

65. Feringa, B.L.; van Delden, R.A.; Koumura, N.; Geertsema, E.M. Chiroptical Molecular Switches. Chem. Rev. 2000, 100, 1789-1816. [CrossRef] [PubMed]

66. Zapata, F.; Fernández-González, M.Á.; Rivero, D.; Álvarez, Á.; Marazzi, M.; Frutos, L.M. Toward an Optomechanical Control of Photoswitches by Tuning Their Spectroscopical Properties: Structural and Dynamical Insights into Azobenzene. J. Chem. Theory Comput. 2014, 10, 312-323. [CrossRef] [PubMed]

67. Chang, V.Y.; Fedele, C.; Priimagi, A.; Shishido, A.; Barrett, C.J. Photoreversible soft azo dye materials: Toward optical control of bio-interfaces. Adv. Opt. Mater. 2019, 7, 1900091. [CrossRef]

68. Diaz Costanzo, G.; Ribba, L.; Goyanes, S.; Ledesma, S. Enhancement of the optical response in a biodegradable polymer/azo-dye film by the addition of carbon nanotubes. J. Phys. D: Appl. Phys. 2014, 47, 135103/1-135103/8. [CrossRef]

69. Georgiev, A.; Dimov, D.; Stoilova, A.; Markova, F.; Nazarova, D. Vapor deposited nanocomposite films of perylene bis azo-imides with improved photoresponsiveness by visible light. Opt. Mater. 2019, 89, 5-13. [CrossRef]

70. Zhang, L.; Cole, $\mathrm{M}$. $\mathrm{TiO}_{2}$-assisted phtoisomerization of azo dyes using self-assembled monolayers: Case study on para-methyl red towards solar-cell applications. ACS Appl. Mater. Interfaces 2014, 6, 3742-3749. [CrossRef] [PubMed]

71. Raposo, M.; Manuela, M.; Sousa, A.M.R.C.; Fonseca, A.; Mauricio, C.; Kirsch, G. Donor-acceptor substituted thienylpyrrole azo dyes: Synthesis, solvatochromic and electrochemical properties. Mater. Sci. Forum 2006, 514, 103-107. [CrossRef]

72. Churikov, V.M.; Hsu, C.-C. Photoinduced third-order nonlinear optical phenomena in azo-dye polymers. In Photoreactive Organic Thin Films; Sekkat, Z., Knoll, W., Eds.; Academic Press: Waltham, MA, USA, 2002; pp. 365-395.

73. Chigrinov, V.; Kwok, H.S.; Takada, H.; Takatsu, H. Photoaligning by azo-dyes: Physics and applications. Liq. Cryst. Today 2005, 14, 1-15. [CrossRef] 
74. Simoni, F.; Francescangeli, O. Effects of light on molecular orientation of liquid crystals. J. Phys. Condens. Mater. 1999, 11, R439-R487. [CrossRef]

75. Lucchetti, L.; Simoni, F. Light-induced adsorption and desorption in Methyl-Red-doped liquid crystals: A review. Liq. Cryst. Rev. 2015, 3, 79-98. [CrossRef]

76. Kumar, V.; Ye, Z.; Jiang, H.; Shi, Y.; Li, K.; Gerard, D.; Luo, D.; Mu, Q.; Liu, Y.J. Highly Stable Pretilted Homeotropic Alignment of Liquid Crystals Enabled by In Situ Self-Assembled Dual-Wavelength Photoalignment. ACS Appl. Electr. Mater. 2020, 2, $2017-2025$. [CrossRef]

77. Kundu, S.; Lee, M.-H.; Lee, S.H.; Kang, S.-W. In Situ Homeotropic Alignment of Nematic Liquid Crystals Based on Photoisomerization of Azo-Dye, Physical Adsorption of Aggregates, and Consequent Topographical Modification. Adv. Mater. 2013, 25, 3365-3370. [CrossRef]

78. Yeung, C.L.; Charlesworth, S.; Iqbal, P.; Bowen, J.; Preece, J.A.; Mendes, P.M. Different Formation Kinetics and Photoisomerization Behavior of Self-Assembled Monolayers of Thiols and Dithiolanes Bearing Azobenzene Moieties. Phys. Chem. Chem. Phys. 2013, 15, 11014-11024. [CrossRef] [PubMed]

79. Kasha, M.; Rawls, H.R.; El-Bayoumi, M.A. The Excition Model in Molecular Spectroscopy. Pure Appl. Chem. 1965, 11, 371-392. [CrossRef]

80. Tong, X.; Cui, L.; Zhao, Y. Confinement Effects on Photoalignment, Photochemical Phase Transition, and Thermochromic Behavior of Liquid Crystalline Azobenzene-Containing Diblock Copolymers. Macromolecules 2004, 37, 3101-3112. [CrossRef]

81. Menzel, H.; Weichart, B.; Schmidt, A.; Paul, S.; Knolls, W.; Stumpe, J.; Fischer, T. Small -Angle X-ray Scattering and UltravioletVisible Spectroscopy Studies on the Structure and Structural Changes in Langmuir-Blodgett Films of Polyglutamates with Azobenzene Moieties Tethered by Alkyl Spacers of Different Length. Langmuir 1994, 10, 1926-1933. [CrossRef]

82. Stumpe, J.; Fischer, T.; Menzel, H. Langmuir-Blodgett Films of Photochromic Polyglutamates. 9. Relation between Photochemical Modification and Thermotropic Properties. Macromolecules 1996, 29, 2831-2842. [CrossRef]

83. Shimomura, M.; Kunitake, T. Fluorescence and Photoisomerization of Azobenzene-Containing Bilayer Membranes. J. Am. Chem. Soc. 1987, 109, 5175-5183. [CrossRef]

84. Tamai, N.; Miyasaka, H. Ultrafast Dynamics of Photochromic Systems. Chem. Rev. 2000, 100, 1875-1890. [CrossRef]

85. He, Y.; Wang, R.; Sun, C.; Liu, S.; Zhou, J.; Zhang, L.; Jiao, T.; Peng, Q. Facile Synthesis of Self-Assembled NiFe Layered Double Hydroxide-Based Azobenzene Composite Films with Photoisomerization and Chemical Gas Sensor Performances. ACS Omega 2020, 5, 3689-3698. [CrossRef]

86. Zhuang, X.-D.; Chen, Y.; Liu, G.; Zhang, B.; Neoh, K.-G.; Kang, E.-T.; Zhu, C.-X.; Li, Y.-X.; Niu, L.-J. Preparation and memory performance of a nanoaggregated Dispersed Red 1-functionalized poly (N-vinylcarbazole) film via solution-phase self-assembly. Adv. Funct. Mater. 2010, 20, 2916-2922. [CrossRef]

87. Zakrevskyy, Y.; Stumpe, J.; Faul, C.F.J.A. Supramolecular Approach to Optically Anisotropic Materials: Photosensitive Ionic Self-assembly Complexes. Adv. Mater. 2006, 18, 2133-2136. [CrossRef]

88. Vasantha, V.A.; Chen, J.; Zhao, W.; van Herk, A.M.; Parthiban, A. Reversible Photo- and Thermoresponsive, Self-Assembling Azobenzene Containing Zwitterionic Polymers. Langmuir 2019, 35, 1465-1474. [CrossRef]

89. Kim, S.H.; Park, Y.M.; Lee, C.S.; Son, Y.A. Self-Assembly Fabrication Using Diazo Coupling Dye and Spiroxazine. Mol. Cryst. Liq. Cryst. 2008, 491, 94-102. [CrossRef]

90. He, J.-A.; Bian, S.; Li, L.; Kumar, J.; Tripathy, S.K.; Samuelson, L.A. Photochemical Behavior and Formation of Surface Relief Grating on Self-Assembled Polyion/Dye Composite Film. J. Phys. Chem. B 2000, 104, 10513-10521. [CrossRef]

91. Hansda, C.; Dutta, B.; Chakraborty, U.; Singha, T.; Hussain, S.A.; Bhattacharhee, D.; Paul, S.; Paul, P.K. Photophysical Behavior of Layer-by-layer Electrostatic Self-assembled Film of Azo Dye Chromotrope-2R and a Polycation. J. Lumin. 2016, 178, 347-355. [CrossRef]

92. Cui, L.; Dahmane, S.; Tong, X.; Zhu, L.; Zhao, Y. Using Self-assembly to Prepare Multifunctional Diblock Copolymers Containing Azopyridine Moiety. Macromolecules 2005, 38, 2076-2084. [CrossRef]

93. Hu, D.; Hu, Y.; Huang, W.; Zhang, Q. Hydrogen Bonded Supermolecular azopolymers: A Media for Multilayered and Polarizationmulitiplexed Data Storage Based Two-photon Process. Proc. SPIE 2012, 8559, 85590.

94. Dalkiranis, G.G.; Therezio, E.M.; da Silva, M.A.T.; Pocas, L.C.; Duarte, J.L.; Laureto, E.; Dias, I.F.L.; Tozoni, J.R.; Silva, R.A.; Marletta, A. Annealing temperature effects on the azodye photoisomerization processes of layer-by-layer self-assembled poly(pphenylenevinylene)/Congo red thin films. J. Lumin. 2013, 134, 842-846. [CrossRef]

95. Moldenhauer, D.; Groehn, F. Nanoassemblies with Light-responsive Size and Density from Linear Flexible Polyelectrolytes. J. Polym. Sci. Part B: Polym. Phys. 2013, 51, 802-816. [CrossRef]

96. Jin, C.; Zhang, T.; Liu, F.; Wang, L.; Yin, Q.; Xiao, D. Fabrication of size controllable polymeric hollow nanospheres containing azo functional groups via ionic self-assembly. RSC Adv. 2014, 4, 8216-8223. [CrossRef]

97. Jin, C.; Zhao, Y.; Wang, H.; Lin, K.; Yin, Q. Synthesis and self-assembly of side-chain azocomplex for preparation of solid and hollow nanosphere. Colloid Polym. Sci. 2012, 290, 741-749. [CrossRef]

98. Jin, C.; Zhang, T.; Liu, F.; Wang, L.; He, M.; Yuan, T.; Jiang, B.; Xiao, D.; Yin, Q. Photoinduced deformation of hollow nanospheres formed by the self-assembly of amphiphilic random copolymers and small azo molecules. RSC Adv. 2014, 4, 45890-45894. [CrossRef]

99. Zhang, T.; Jin, C.; Wang, L.; He, M.; Yuan, T.; Yin, Q. One-step synthesis of hollow polymeric nanospheres: Self-assembly of amphiphilic azo polymers via hydrogen bond formation. RSC Adv. 2014, 4, 36882-36889. [CrossRef] 